\title{
Crustal Evolution of the Mid-Atlantic Ridge near the Fifteen-Twenty Fracture Zone in the last 5 Ma
}

\author{
Toshiya Fujiwara \\ Department of Geology and Geophysics, Woods Hole Oceanographic Institution, Woods Hole, Massachusetts, USA \\ Now at Deep-Sea Research Department, Japan Marine Science and Technology Center, Yokosuka, 237-0061 Japan. \\ (toshi@jamstec.go.jp)
}

\section{Jian Lin}

Department of Geology and Geophysics, Woods Hole Oceanographic Institution, Woods Hole, Massachusetts 02543, USA (jlin@whoi.edu)

\section{Takeshi Matsumoto}

Deep-Sea Research Department, Japan Marine Science and Technology Center, Yokosuka, 237-0061 Japan

(takeshi@jamstec.go.jp)

\section{Peter B. Kelemen and Brian E. Tucholke}

Department of Geology and Geophysics, Woods Hole Oceanographic Institution, Woods Hole, Massachusetts 02543, USA (peterk@whoi.edu; btucholke@whoi.edu)

\section{John F. Casey}

Department of Geosciences, University of Houston, Houston, Texas 77204,USA (jfcasey@uh.edu)

[1] The Mid-Atlantic Ridge around the Fifteen-Twenty Fracture Zone is unique in that outcrops of lower crust and mantle rocks are extensive on both flanks of the axial valley walls over an unusually long distance along-axis, indicating a high ratio of tectonic to magmatic extension. On the basis of newly collected multibeam bathymetry, magnetic, and gravity data, we investigate crustal evolution of this unique section of the Mid-Atlantic Ridge over the last $5 \mathrm{Ma}$. The northern and southern edges of the study area, away from the fracture zone, contain long abyssal hills with small spacing and fault throw, well lineated and high-amplitude magnetic signals, and residual mantle Bouguer anomaly (RMBA) lows, all of which suggest relatively robust magmatic extension. In contrast, crust in two ridge segments immediately north of the fracture zone and two immediately to the south is characterized by rugged and blocky topography, by low-amplitude and discontinuous magnetization stripes, and by RMBA highs that imply thin crust throughout the last $5 \mathrm{Ma}$. Over these segments, morphology is typically asymmetric across the spreading axis, indicating significant tectonic thinning of crust caused by faults that have persistently dipped in only one direction. North of the fracture zone, however, megamullions are that thought to have formed by slip on long-lived normal faults are found on both ridge flanks at different ages and within the same spreading segment. This unusual partitioning of megamullions can be explained either by a ridge jump or by polarity reversal of the detachment fault following formation of the first megamullion.

Components: 11,373 words, 16 figures, 1 table.

Keywords: Fifteen-twenty fracture zone; morphology; magnetic anomaly; gravity anomaly; megamullion.

Index Terms: 8122 Tectonophysics: Dynamics, gravity and tectonics; 3035 Marine Geology and Geophysics: Midocean ridge processes. 
Received 12 April 2002; Revised 1 September 2002; Accepted 4 October 2002; Published 8 March 2003.

Fujiwara, T., J. Lin, T. Matsumoto, P. B. Kelemen, B. E. Tucholke, and J. F. Casey, Crustal Evolution of the Mid-Atlantic Ridge near the Fifteen-Twenty Fracture Zone in the last 5 Ma, Geochem. Geophys. Geosyst., 4(3), 1024, doi:10.1029/2002GC000364, 2003.

\section{Introduction}

[2] The Fifteen-Twenty Fracture Zone offsets the Mid-Atlantic Ridge (MAR) by about $200 \mathrm{~km}$ in the north Atlantic (Figure 1). Within $\sim 60 \mathrm{~km}$ of the fracture zone, volcanic crust is locally absent and rocks of the lower crust and upper mantle are commonly found along the rift axis [Rona et al., 1987; Dick et al., unpublished data, 1990; Cannat et al., 1992, 1997; Bougault et al., 1993; Cannat and Casey, 1995; Lagabrielle et al., 1998]. These outcrops are not restricted to the vicinity of axial discontinuities but extend over the whole length of segments between $14^{\circ} 30^{\prime} \mathrm{N}$ and $15^{\circ} 50^{\prime} \mathrm{N}$. They are among the most extensive exposures of lower crust and mantle known on the MAR. Along this portion of the ridge, seafloor morphology is characterized by irregular terrain, with short and oblique fault scarps observed on both ridge flanks [Cannat et al., 1997] (Figure 1).

[3] This area of the MAR has several unique characteristics. (1) Ultramafic rocks crop out on both sides of the axial valley, in contrast to other portions of the MAR where ultramafic and gabbroic rocks are preferentially exposed at inside corners of ridge-offset intersections [see, e.g., Tucholke and Lin, 1994, for review]. Such exposures, and associated residual gravity highs [Escartin and Cannat, 1999], suggest greatly reduced magma supply along a substantial portion of the ridge axis. (2) The compositions of basalt samples from this region are consistent with melting of an enriched mantle source. A geochemical anomaly is centered at $14^{\circ} \mathrm{N}$ and extends north across the Fifteen-Twenty Fracture Zone to $17^{\circ} \mathrm{N}$. The anomaly is characterized by high $\mathrm{La} / \mathrm{Sm}, \mathrm{Nb} / \mathrm{Zr}$, ${ }^{206} \mathrm{~Pb} /{ }^{204} \mathrm{~Pb}$, and ${ }^{87} \mathrm{Sr} /{ }^{86} \mathrm{Sr}$ ratios and low ${ }^{3} \mathrm{He} /{ }^{4} \mathrm{He}$ ratios of basalt samples [Peyve et al., 1988b; Staudacher et al., 1989; Casey et al., 1992; Dosso et al., 1991, 1993; Bonatti et al., 1992; Sobolev et al., 1992a, 1992b]. Typically, such characteristics are associated with the presence of a mantle "hot spot", with large amounts of melting of a hightemperature, fertile mantle source yielding an unusually large thickness of igneous crust. (3) Serpentinized peridotite samples show high $\mathrm{Cr} /$ $(\mathrm{Al}+\mathrm{Cr})$ ratios in spinel and high $\mathrm{Mg} /(\mathrm{Mg}+\mathrm{Fe})$ in olivine [Bougault et al., 1988; Peyve et al., 1988a; Xia et al., 1991; Bonatti et al., 1992; Cannat et al., 1992; Dick and Kelemen, 1992; Sobolev et al., 1992c] which reflect high degrees of mantle melting. Therefore, as noted by many previous works, there is an apparent contradiction between the reduced magma supply inferred from the extensive exposure of ultramafic rocks (1 above) and the substantial melting of fertile, hot spot mantle inferred from the geochemistry of basalts and peridotites (2 and 3) [Xia et al., 1992; Casey et al., 1994].

[4] Because this is an area of strong interest for ocean drilling, and to obtain data that might help resolve the contradictions noted above, we conducted a geophysical survey and submersible dive program around the Fifteen-Twenty Fracture Zone in $1998(\mathrm{R} / \mathrm{V}$ Yokosuka Cruise YK98-05; MODE98, Leg 1) [Kelemen et al., 1998; Matsumoto et al., 1998]. We used the submersible Shinkai 6500 to characterize potential drill sites for a proposed ODP study of upper mantle structure and geochemistry. Between dives of the submersible, we conducted a geophysical survey to collect multibeam bathymetry, magnetic, and gravity data to 5 m.y. off-axis [Fujiwara et al., 1999]. By extending the survey to this distance, we hoped to resolve the longer-term record of magmatic vs. amagmatic extension in this area and thus gain new insight into processes that might explain the discrepancy between geological and geochemical observations at the present ridge axis. In addition, because mantle is extensively exposed on both 


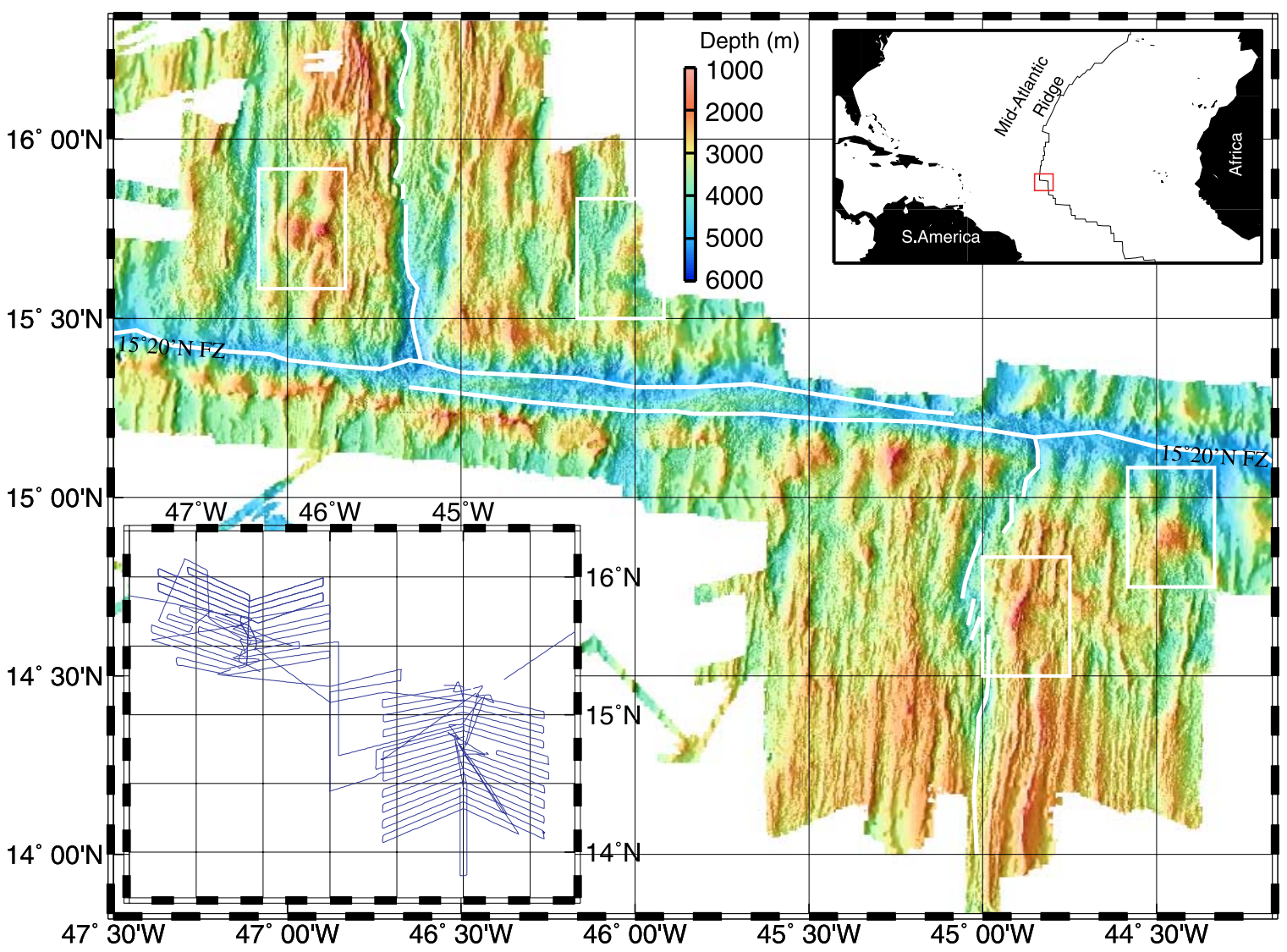

Figure 1. Shaded relief bathymetry from multibeam survey of the Mid-Atlantic Ridge in the vicinity of the FifteenTwenty Fracture Zone. White lines mark the fracture zone and bathymetric lows within the axial valleys. White boxes mark locations of detailed maps in Figure 3. The upper right inset shows the location of the study area, and the lower left inset shows tracks of the YK98-05 survey in 1998.

sides of the axial valley, Cannat et al. [1997] and Lagabrielle et al. [1998] suggested that a model of asymmetric extension and mantle exhumation along a single major fault [e.g., Tucholke and Lin, 1994] could not be applied to this portion of the MAR. We expected that our off-axis survey would provide data necessary to assess the degree of across-axis asymmetry or symmetry of tectonic processes that are responsible for the exhumation of lower crust and mantle in this region.

\section{Data Sources}

\subsection{Multibeam Bathymetry}

[5] Ship tracklines were laid out at an angle of $10^{\circ}-30^{\circ}$ to predicted plate flowlines to assure that real morphological features, which are normally oriented parallel or perpendicular to flowlines, could be distinguished from artifacts caused by multibeam instrumental beam-point errors (Figure 1). Track spacing near the outer edge of the survey was about $6-7 \mathrm{~km}$, while that over the crest of the rift mountain was about $5 \mathrm{~km}$, yielding almost complete bathymetric coverage except for occasional small gaps over shallow ridges. The survey covered a region from $60 \mathrm{~km}$ north to $140 \mathrm{~km}$ south of the fracture zone, extending to $70 \mathrm{~km}$ offaxis on both ridge flanks. Differential Global Positioning System (D-GPS) and World Geodetic System (WGS) 84 were used in ship navigation.

[6] Bathymetric data were collected using a HS-10 multinarrow beam echo sounder system, which has 45 beams and a swath width of $90^{\circ}$, covering an across-track width twice as wide as the water depth [Oshida and Furuta, 1995]. The spatial resolution of the multibeam data is $100-200 \mathrm{~m}$ at the water depths in the survey area. The sound velocity profile in the water column was calculated using measure- 
ments from an expendable bathothermograph (XBT) at $15^{\circ} 43.5^{\prime} \mathrm{N}, 46^{\circ} 44.5^{\prime} \mathrm{W}$. Artifacts in the data included occasional "curl-up" of the outermost beams and a few spurious depth readings. Spurious, clearly unreliable beam points comprise $\sim 5 \%$ of the total data volume and were edited out manually. We merged our bathymetric data with multibeam bathymetry collected onboard the N/O Atalante [Escartin and Cannat, 1999] to create a new bathymetric map that is significantly broader than the previous geophysical study. The Atalante data complements our coverage north of $16^{\circ} \mathrm{N}$, along the fracture zone, and south of $14^{\circ} 10^{\prime} \mathrm{N}$. Global bathymetric data from ETOPO5 [National Geophysical Data Center $(N G D C), 1988]$ were used to fill unsurveyed areas only for the purpose of terrain corrections in magnetic and gravity data analysis.

\subsection{Magnetics}

[7] Geomagnetic total force data were obtained using a STC10 surface-towed proton precession magnetometer made by the Kawasaki Geol. Eng. Co. [Oshida and Furuta, 1995]. The sensor was towed $350 \mathrm{~m}$ behind the ship with a sampling interval of $20 \mathrm{~s}$. After position correction to account for sensor cable length, the geomagnetic total force anomaly was calculated by subtracting the International Geomagnetic Reference Field (IGRF) 1995 model [International Association of Geomagnetism and Aeronomy (IAGA), 1995]. The resultant data yielded crossover errors of $3.4 \mathrm{nT}$ and RMS standard deviation of $22.3 \mathrm{nT}$. Diurnal variation was estimated using the observed anomaly differences at track crossover points to produce an acceptable diurnal variation curve [Buchanan et al., 1996]. After correction based on the estimated diurnal variation curve, the standard deviation was reduced to $13.5 \mathrm{nT}$.

\subsection{Gravity}

[8] Marine gravity data along the ship tracks were collected using a S-63 LaCoste \& Romberg shipboard gravimeter at a sampling interval of $10 \mathrm{~s}$. Shipboard gravity data were tied to absolute gravity values at calibration stations in San Juan, Puerto Rico, and Lisbon, Portugal, using a G-1093 LaCoste \& Romberg land gravimeter. After cor- recting for Eötvös effects and sensor drift rate of $0.12 \mathrm{mGal} /$ day, free-air gravity anomaly was calculated by subtracting from the corrected data the theoretical gravity formula of the Geodetic Reference System 1967 [International Association of Geodesy (IAG), 1967]. Crossover errors at a total of 203 track crossing points yield an RMS standard deviation of $3.4 \mathrm{mGal}$. We also merged our gravity data with data collected onboard the N/O Atalante [Escartín and Cannat, 1999]. Crossover errors between the two sets have a standard deviation of $3.5 \mathrm{mGal}$. The observed free-air gravity anomaly data were merged with the gravity anomaly data derived from satellite altimetry [Sandwell and Smith, 1997] to extend coverage to areas where no shipboard gravity data were available.

\section{Bathymetry and Geological Features}

[9] The Fifteen-Twenty Fracture Zone is oriented in a direction of $\mathrm{N} 94^{\circ}-98^{\circ} \mathrm{E}$ and in its transform section it exhibits a relatively broad valley (Figure 1). The transform domain shows a relatively broad valley. Several authors have proposed that the triple junction between the North American, South American, and African plates should be situated between $10^{\circ} \mathrm{N}$ and $20^{\circ} \mathrm{N}$ [e.g., Roest and Collette, 1986; Müller and Smith, 1993], and the broad transform valley may be created by changes in spreading direction that accompanied northward migration of the triple junction after 10 Ma [Roest and Collette, 1986; Müller and Smith, 1993]. The trend of the fracture zone is essentially parallel to the spreading direction estimated by a global analysis of the plate motion of South America-Africa $\left(\mathrm{N} 94^{\circ} \mathrm{E}\right)$ and North America-Africa $\left(\mathrm{N} 100^{\circ} \mathrm{E}\right)$ [DeMets et al., 1990].

\subsection{North of the Fifteen-Twenty Fracture Zone}

[10] Within our survey area, we interpret three ridge segments north of the fracture zone. The segments are separated by non-transform discontinuities that show little or no offset either in the axial valley or off-axis. Dashed lines in Figure 2 show the interpreted segment boundaries, which are based on combined analysis of disruptions in along-isochron 


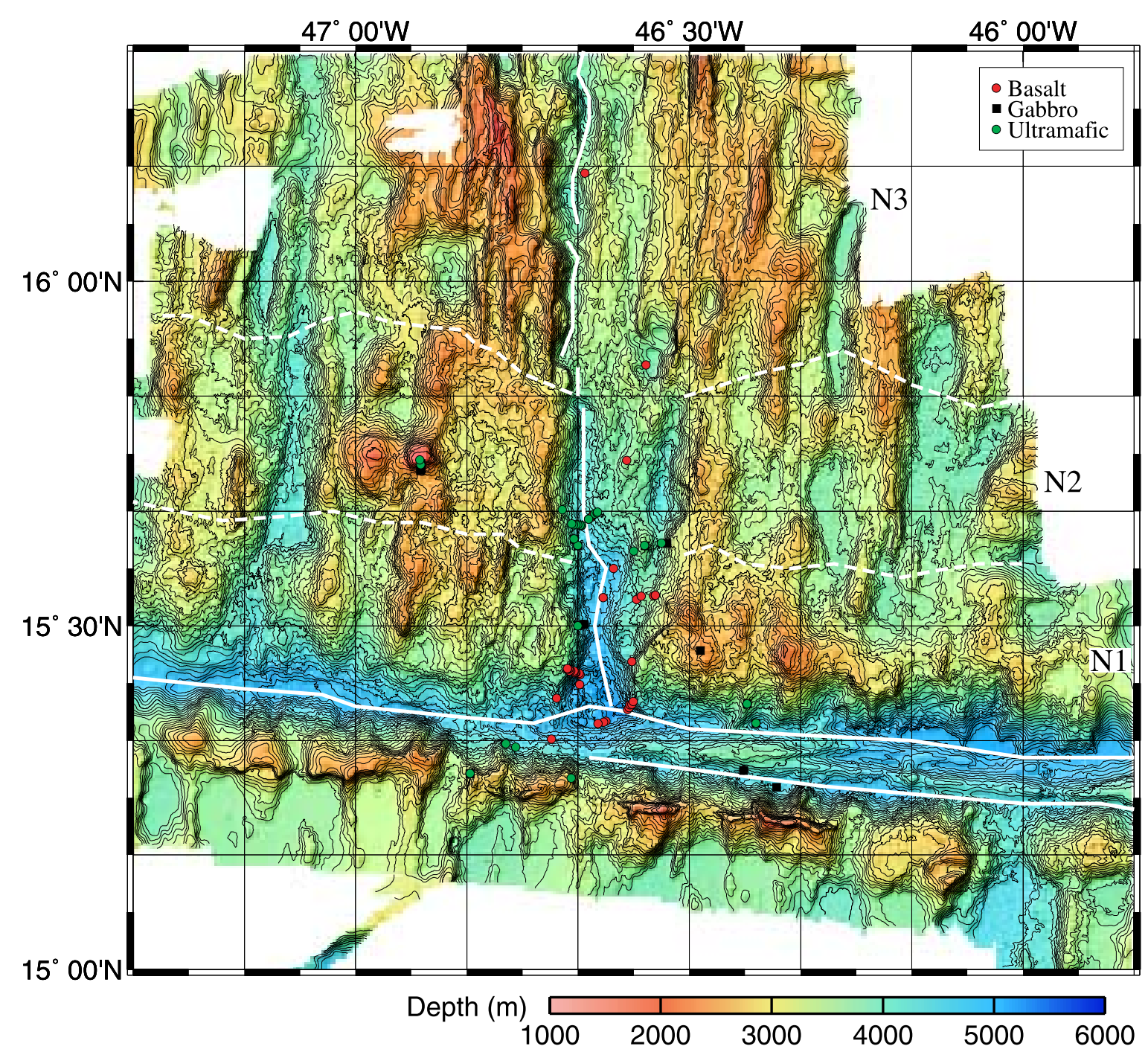

Figure 2. Detailed bathymetry and rock sample locations in the northern half of the study area. Thin and thick contour lines are at $100 \mathrm{~m}$ and $1000 \mathrm{~m}$ intervals, respectively. Thick white lines locate bathymetric lows within the axial valley and the fracture zone. Dashed white lines show interpreted segment boundaries. Segments are named N1, N2, and N3 from south to north. Rock samples are from American, French, and Russian dredges, as well as from French and Japanese submersible dives. Sample locations from Rona et al. [1987], Bougault et al. [1993], Cannat et al. [1997], and Dick, H. J. B., R. T. Beaubouef, C. Xia, and Shipboard Party, Report on Dredge Hauls from the $15^{\circ} 20^{\prime}$ Fracture Zone Akademik Boris Petrov Cruise 16, Leg 2, (unpublished data, 1990), shared via personal communication from H.J.B. Dick (2002).

continuity of bathymetric, magnetic, and gravity data. By itself, no one of these data sets necessarily defines discontinuities, and this is typical of smallto zero-offset segment boundaries. Hereafter, we refer to the segments defined here as N1, N2, and N3, from south to north.

[11] The flanks of segment N3 show relatively long abyssal hills sub-parallel to the ridge axis, with $\sim 3-5 \mathrm{~km}$ spacing and a few hundred meters of relief. There is a southward transition from this linear terrain to an irregular terrain with shorter, more widely spaced, and oblique fault scarps near $15^{\circ} 50^{\prime} \mathrm{N}$. The transition falls between segments N2 and N3 and has a southward-pointing that extends up to $\sim 40 \mathrm{~km}$ off axis. This suggests southward propagation of the discontinuity during the last few million years. At off-axis distances greater than $\sim 40 \mathrm{~km}$, there is little morphological contrast between the two segments. 


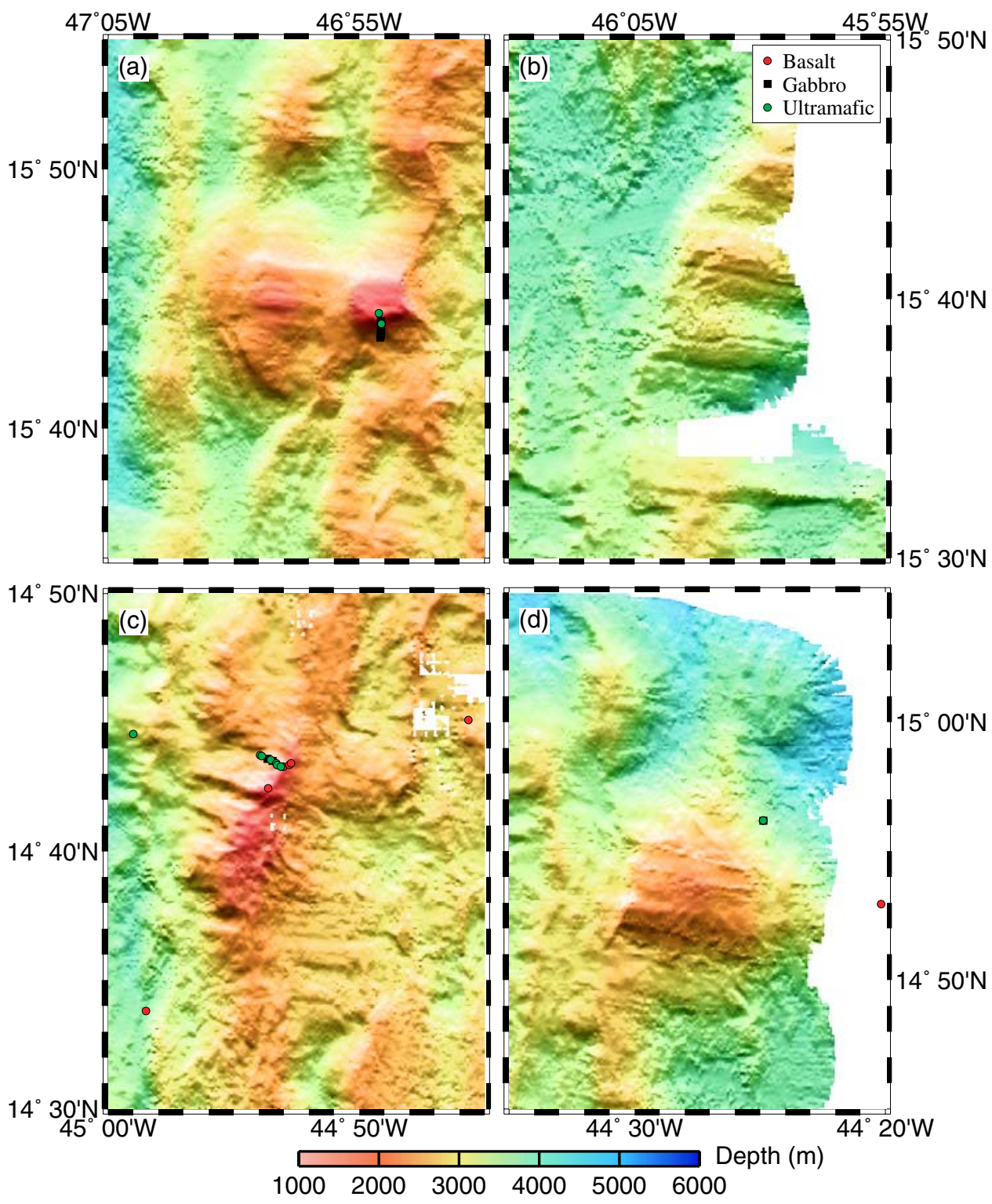

Figure 3. Detailed shaded relief of corrugated megamullion surfaces illuminated from the north on $100 \mathrm{~m}$ gridded multibeam bathymetry. See Figure 1 for locations. Megamullions are (a) on the western flank of segment N2 $40 \mathrm{~km}$ off-axis, (b) on the eastern flank of segment N2 $~ 80$ km off-axis, (c) and (d) on the eastern flank of segment S2, 10 $\mathrm{km}$ and $\sim 50 \mathrm{~km}$ off-axis, respectively. Symbols mark locations of rock samples with the same notation as in Figure 2.

[12] The ridge flanks of segment N2 are characterized by irregular and blocky topography, thought to reflect variable fault and volcanic patterns. Seafloor bathymetry is asymmetric across the spreading axis. On the western flank, elevated topography extends from the ridge axis out to $\sim 47^{\circ} 05^{\prime} \mathrm{W}$. On the eastern flank, seafloor averages about $500 \mathrm{~m}$ to $1,000 \mathrm{~m}$ deeper. Between $46^{\circ} 50^{\prime} \mathrm{W}$ and $47^{\circ} 00^{\prime} \mathrm{W}$ at $15^{\circ} 45^{\prime} \mathrm{N}$, a dome-shaped megamullion structure, capped by a corrugated surface with lineations parallel to spreading direction is observed (Figure 3a). Observations from the Shinkai 6500 submersible dive at $46^{\circ} 54^{\prime} \mathrm{W}, 15^{\circ} 44^{\prime} \mathrm{N}$ show that the megamullion surface consists of lower-crustal gabbro and mantle peridotite [Casey et al., 1998; Escartín and MacLeod, 2001; MacLeod and Escartín, 2001]. It is notable that a similar corrugated and domed surface appears in the older crust at the same latitude on the eastern flank of segment N2, about $70 \mathrm{~km}$ off-axis (Figure 3b). 


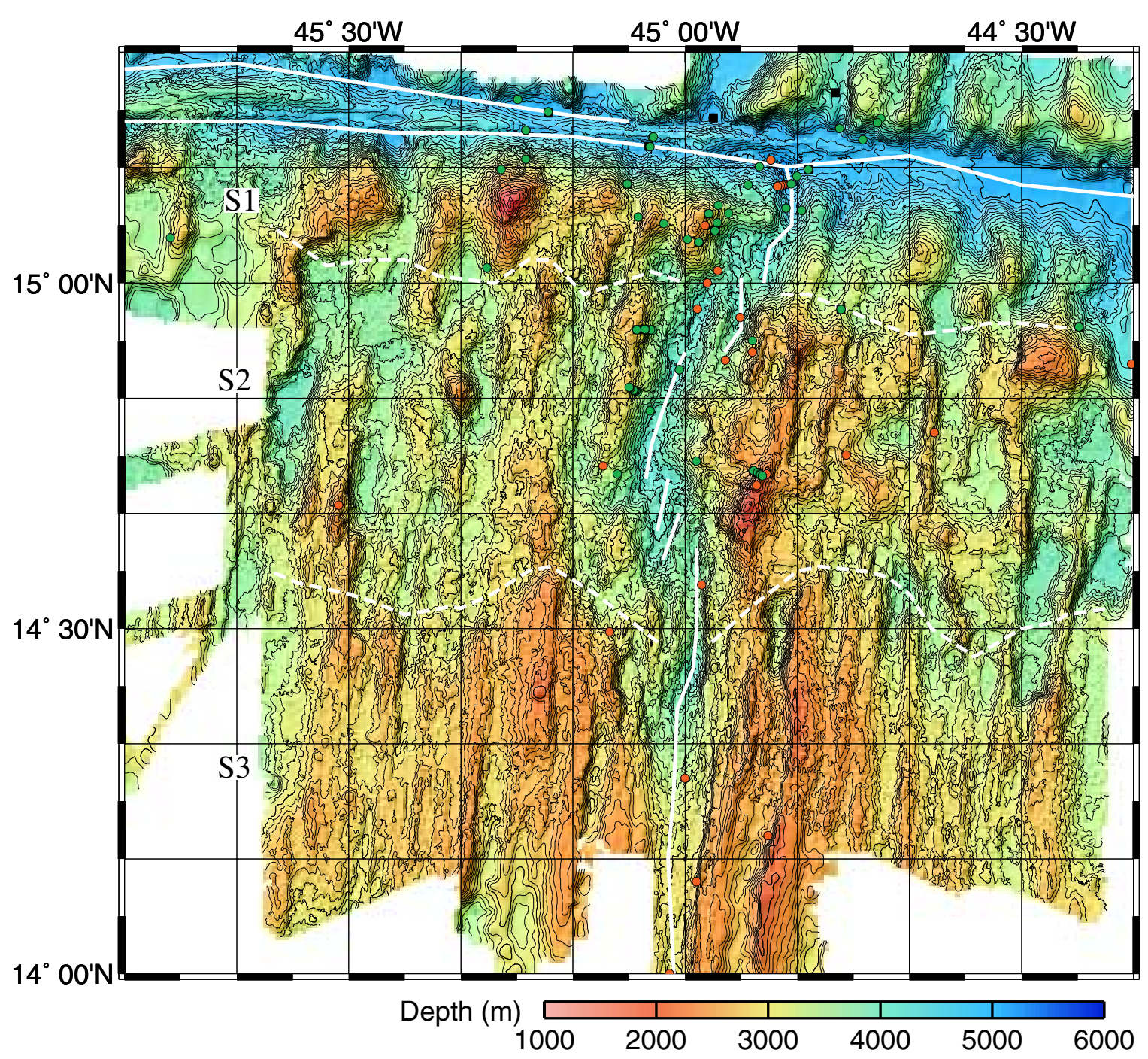

Figure 4. Detailed bathymetry and rock sample locations in the southern half of the survey area, presented as in Figure 2. Spreading segments S1, S2, and S3 are identified.

[13] The boundary between segments N1 and N2 is interpreted to be sub-parallel to the strike of the fracture zone (Figure 2). Segment N1 is about 30 $\mathrm{km}$ in length and has the opposite sense of depth asymmetry on the ridge flanks, compared to segment N2. Elevated, blocky topography is dominant on the eastern flank at the inside corner of the ridge-transform intersection. Somewhat deeper and more lineated abyssal hills appear on outsidecorner crust of the western flank.

[14] Rock lithology appears to vary somewhat between segments. Along the axial valley in segment $\mathrm{N} 1$ and at the ridge-transform intersection, mainly basalt samples were recovered, although both gabbro and peridotite were recovered in the valley walls and on the crest of the inside-corner high (Figure 2). In segment N2, ultramafic rocks were obtained on both walls of the axial valley as well as on elongated structures within the axial valley. There have been no peridotires recovered in segment N3, although the presence of peridotite cannot be ruled out due to the limited number of sampling sites.

\subsection{South of the Fifteen-Twenty Fracture Zone}

[15] We identified three segments south of the fracture zone based on the bathymetric, magnetic, 


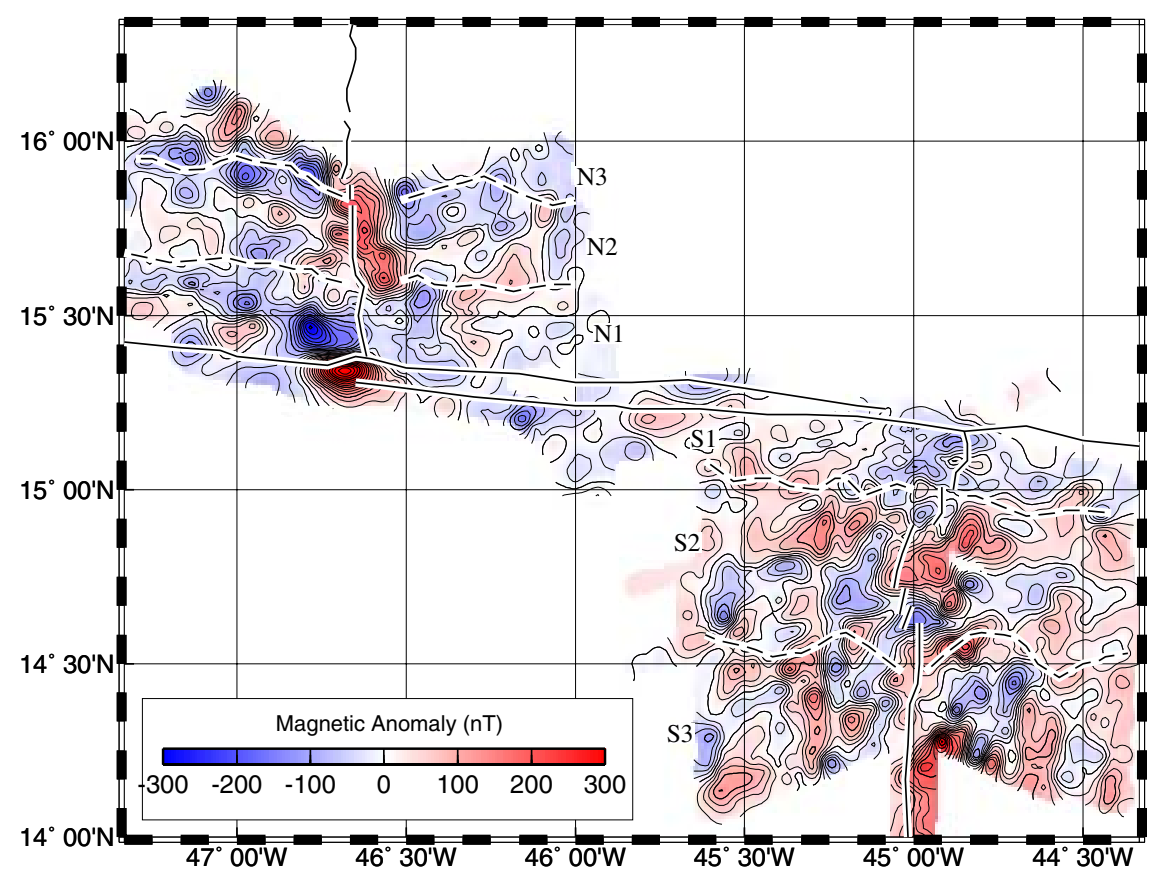

Figure 5. Magnetic anomaly map. Thin and thick lines mark 25 and $100 \mathrm{nT}$ contours, respectively. Bold lines mark bathymetric lows within the axial valley and fracture zone as in Figures 1, 2, and 4. Dashed lines indicate interpreted segment boundaries.

and gravity data (Figure 4), referred as S1, S2, and S3 from north to south. Segment S1 immediately south of the fracture zone is about $20 \mathrm{~km}$ long, has irregular and blocky topography, and shows strongly asymmetric depth across the ridge axis. Massifs on the western, inside corner flank are consistently elevated compared to eastern flank outside corner crust.

[16] At $\sim 15^{\circ} 00^{\prime} \mathrm{N}$, the axial valley is offset to the west between segments S1 and S2. In segment S2, fault scarps are short and irregular, widely spaced, and often oriented obliquely to the direction of plate spreading. The eastern flank is elevated by $500-$ 1,000 m compared to the western flank. The eastern flank has bands of megamullion surfaces corrugated sub-parallel to spreading direction. One set of corrugated surfaces is about $10-15 \mathrm{~km}$ wide and is nearaxis north of the boundary between segments $\mathrm{S} 2$ and S3 (Figure 3c). A second, domed and corrugated surface is found at $44^{\circ} 28^{\prime} \mathrm{W}$, about $60 \mathrm{~km}$ off-axis near the S1/S2 segment boundary (Figure 3d).

[17] From $14^{\circ} 40^{\prime} \mathrm{N}$ to $14^{\circ} 33^{\prime} \mathrm{N}$, the axial valley is offset to the east in en-echelon deeps (Figure 4).
The segment boundary between S2 and S3 at the axis is somewhere between $14^{\circ} 28^{\prime} \mathrm{N}$ and $14^{\circ} 33^{\prime} \mathrm{N}$. Off-axis the S2/S3 segment boundary marks an abrupt transition from the northern, irregular terrain to a southern linear terrain of long ridge-parallel abyssal hills with smaller spacing and more limited throw on faults. Segment S3 on both ridge flanks south of $14^{\circ} 30^{\prime} \mathrm{N}$ has seafloor depths generally shallower than in segments S1 and S2, and the morphology is nearly symmetric across the ridge axis.

[18] Abundant gabbros and peridotites, and fewer basalts, have been collected in segments S1 and S2. Dredging and submersible sampling establish that ultramafic rocks are widely exposed in the elevated massifs of the western flank of segment $\mathrm{S} 1$. There is not enough rock sampling to infer the general lithology of the eastern flank of segment S1, although ultramafic rocks have been collected on the eastern wall of the axial valley. In segment S2, ultramafic rocks have been collected extensively from the rift axis to the crest of the rift mountains down to $14^{\circ} 40^{\prime} \mathrm{N}$. This sampling includes peridotites from the two megamullions (Figures $3 c$ and 


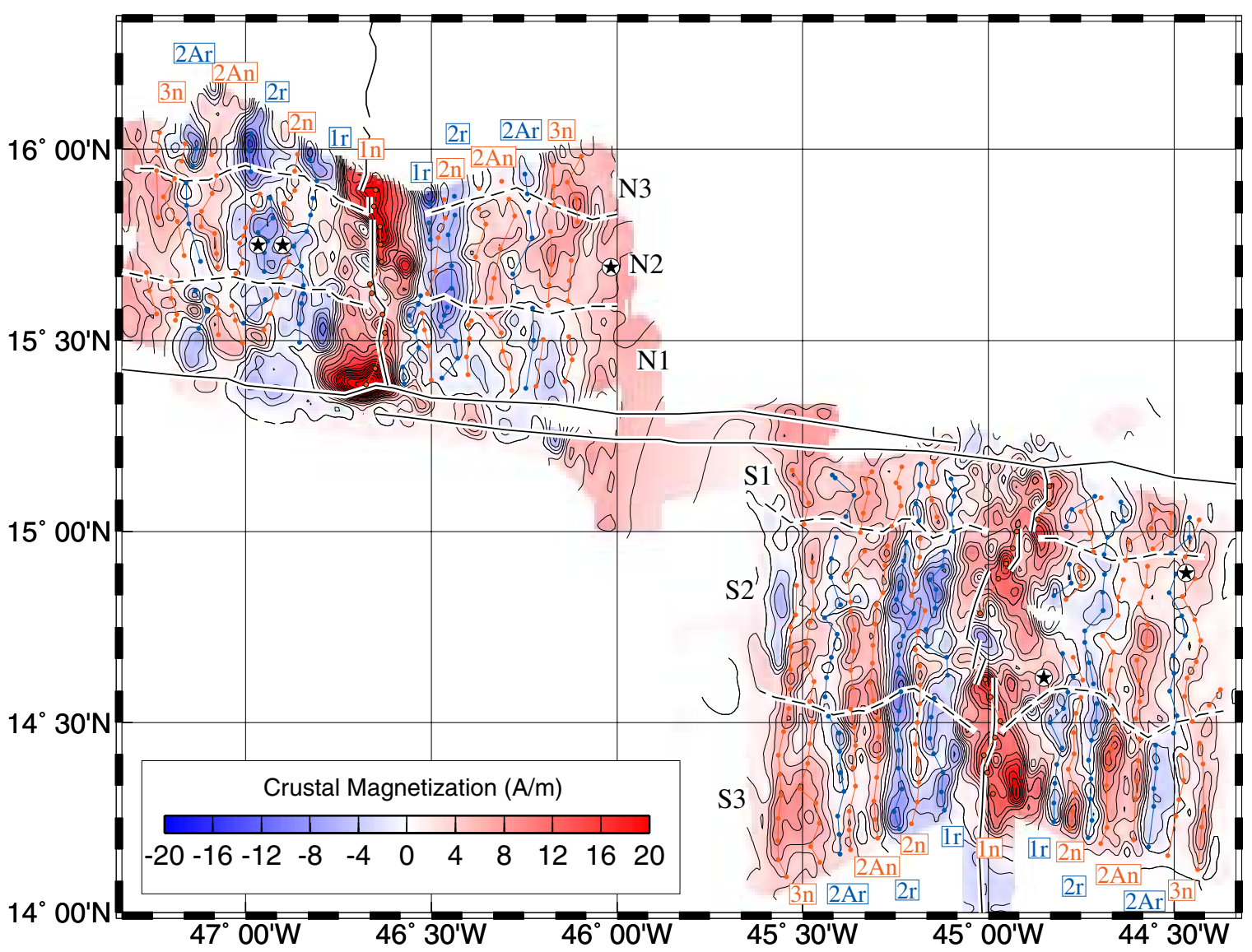

Figure 6. Crustal magnetization calculated from magnetic anomaly. Contours are at $2 \mathrm{~A} / \mathrm{m}$ intervals. Red circles mark peaks of normal polarity anomalies picked along ship track and blue circles mark peaks of reversed polarity anomalies. Stars mark locations of megamullions. Other symbols as in Figure 5.

3d). In contrast, only basalts have been recovered in segment S3.

\section{Magnetic Anomaly and Crustal Magnetization}

\subsection{Magnetic Anomaly Analysis}

[19] Peak-to-trough amplitudes of magnetic anomalies between $14^{\circ} 30^{\prime} \mathrm{N}$ and $15^{\circ} 50^{\prime} \mathrm{N}$ average about $200 \mathrm{nT}$ in the survey region (Figure 5). Exceptionally high amplitudes $(\sim 600 \mathrm{nT})$ appear at the western ridge-transform intersection (RTI), but there is no complementary variation at the eastern RTI. Our data confirm previous studies [Rona et al., 1987; Wooldridge et al., 1992] which showed that overall magnetic anomaly amplitudes in this area are smaller than in other portions of the MAR [e.g., Grindlay et al., 1992; Pariso et al., 1996; Weiland et al., 1996].
[20] Crustal magnetization was calculated to remove skewness due to low magnetic latitude and to correct for effects of seafloor topography. We used the three-dimensional inversion method of Parker and Huestis [1974] and Macdonald et al. [1980]. A uniform magnetic source layer $500 \mathrm{~m}$ thick was assumed. The direction of magnetization in the source layer was assumed to be oriented parallel to a geocentric dipole field. Bandpass filters with cosine tapers for wavelengths between $3-6 \mathrm{~km}$ and between $100-150 \mathrm{~km}$ prevented instabilities during the inversion. The annihilator was added twice to give approximately equal positive and negative magnetization values.

\subsection{Crustal Magnetization}

[21] Calculated crustal magnetization is shown in Figure 6 together with anomaly identifications. Along the axial valley, the central anomaly magnetic 
high locally is low-amplitude and disorganized. In particular, the normal magnetization high is conspicuously missing near $14^{\circ} 45^{\prime} \mathrm{N}$ and $15^{\circ} 40^{\prime} \mathrm{N}$ in segments $\mathrm{S} 2$ and $\mathrm{N} 2$, and it is poorly expressed in segment S1. In contrast, within segment S3, and to a lesser degree in segments $\mathrm{N} 1$ and N3, the central anomaly magnetic high is well developed. Off-axis, segment S3 shows the clearest development of highamplitude and linear magnetic anomalies, and these patterns are symmetrical about the rift axis. The other segments generally exhibit lower amplitude anomalies in irregular form, with varying degrees of cross-axis asymmetry. Notably, the western flank of segment S2 shows relatively linear, well developed anomalies, whereas the eastern flank anomalies are irregular and lower amplitude, particularly close to the ridge axis. Well developed linear anomalies are absent at the locations where megamullions appear in segments N2 and S2 (stars, Figure 6).

[22] To a first order, variations in the magnetic anomaly pattern in the study area appear to reflect the occurrence and thickness of the upper crustal layer. Extrusive basalts are known to be highly magnetized, and they contribute to a large part of the magnetic signal in young oceanic crust [e.g., Tivey, 1996; Fujiwara and Fujimoto, 1998]. Although rock sampling in the study area is highly non-uniform, existing samples show a general, positive correlation between significant occurrence of basalts and magnetic anomaly amplitude. Where the high amplitude anomalies occur at the western RTI, for example, Shinkai 6500 submersible observations and seafloor sampling document an abundance of fresh basalts, and this axial region appears to be the locus of recent volcanic eruptions [Kelemen et al., 1998; Matsumoto et al., 1998]. In contrast, at the eastern RTI basalts are rare, exposures of gabbroic and ultramafic rocks are dominant, and magnetic anomaly amplitudes are low. On a broader scale, segments N2, S1, and S2 also show significant exposures of gabbros and ultramafic rocks in the axial valley (Figures 2 and 4), consistent with low amplitude of magnetization and disorganized lineation patterns there. Similar anomaly character on the ridge flanks in these segments and in segment S1 suggests that basaltic crust is commonly thin or absent in some places and that the segments have had limited basaltic magma supply over the past several million years. Strong and well organized magnetization on the flanks of segment S3 suggests that this segment has been magmatically robust over the same period.

\subsection{Magnetic Age and Spreading Rate}

[23] To examine the history of plate spreading, we identified magnetic isochrons from the magnetization map. Anomalies were picked at locations of peak amplitude of magnetization along ship tracks (dots, Figure 6) and identified using the polarity timescale of Cande and Kent [1995]. The magnetic inversion emphasizes the lateral variations in crustal magnetization but cannot distinguish changes in source thickness or source intensity. Resultant magnetization could be a function of abundance of magnetic rocks instead. For example, in the central anomaly (1n), off-axis crust could be basaltic and thus have higher magnetization than on-axis crust where peridotites crop out. For anomaly 1n, we picked peaks in the central anomaly near the middle of the axial valley, even though there are exceptional highs off-axis at $15^{\circ} 40^{\prime} \mathrm{N}$ and $14^{\circ} 20^{\prime} \mathrm{N}$ (Figure 6). We determined crustal ages out to anomaly 3n-old (4.9 Ma).

[24] Near-axis anomalies are complex and disorganized, making age identification difficult. For segments N1, N2, S1, and S2, there are large differences in distance from anomalies 1r (1.3 Ma) to $1 \mathrm{n}(0 \mathrm{Ma})$ between the two flanks (Figures 7 and 8). In segments N1, N2 and S1, the distance between these isochrons on the western flank is $10-18 \mathrm{~km}$ greater than that on the eastern flank. Possible explanations for such asymmetry include differential tectonic extension, ridge jumps, or a combination of these. If ridge jumps occurred, the ridge axis shifted to the east by $\sim 7 \mathrm{~km}$ in segment $\mathrm{N} 1, \sim 4 \mathrm{~km}$ in $\mathrm{N} 2$, and $\sim 9 \mathrm{~km}$ in S1, respectively. This kind of large-scale asymmetry has occurred only in the past $\sim 1.3$ m.y. and does not appear on the ridge flanks at greater ages.

[25] Full-spreading rate and half-spreading rates were determined by fitting least squaress lines to isochron age versus distance plots (Figures 7 and 8, and Table 1). The mean full spreading rate is 25 

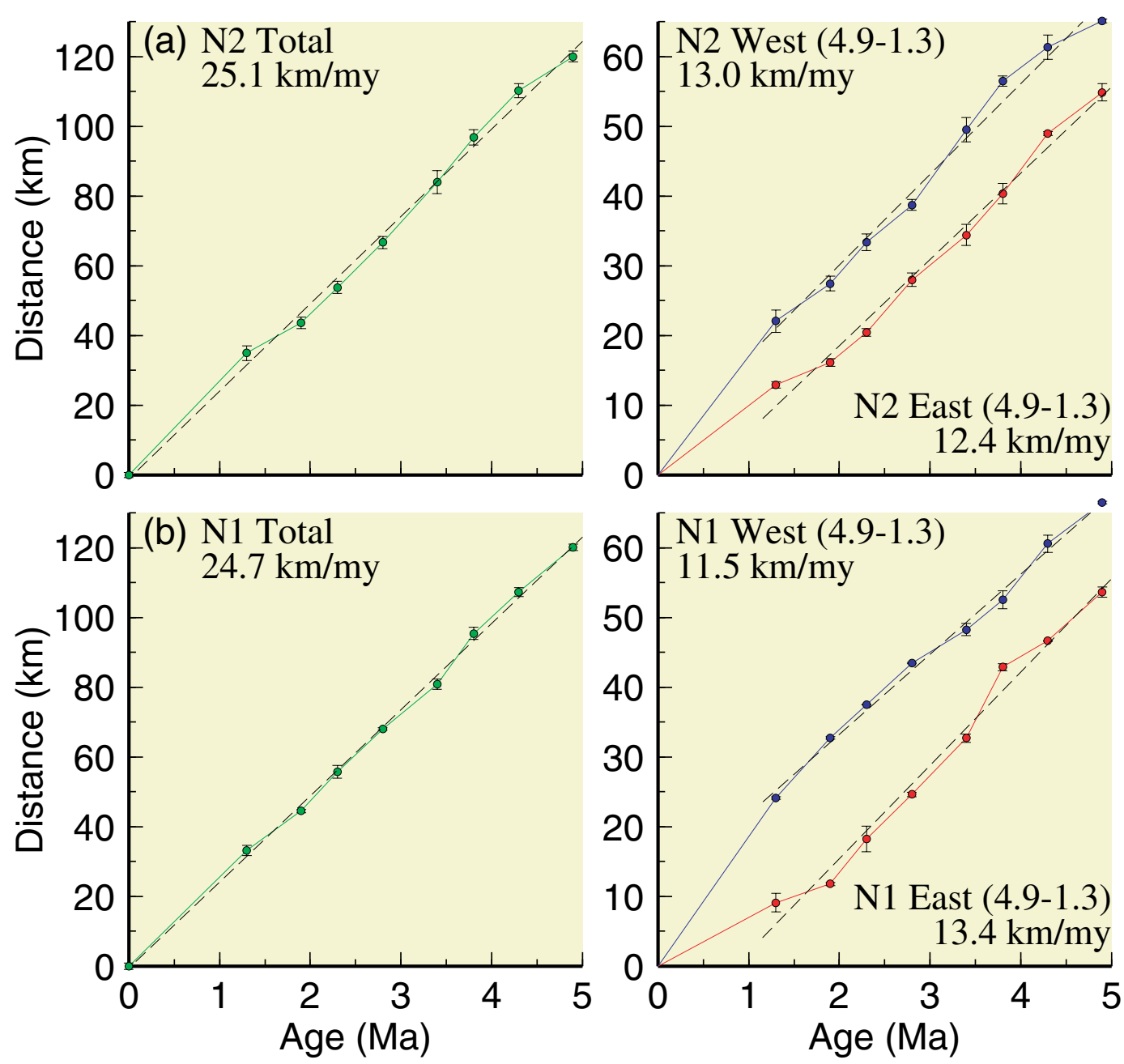

Figure 7. Spreading rate history for segments north of the Fifteen-Twenty Fracture Zone. (a) Segment N2 full spreading rate (left), and half rates for eastern and western flanks (right). (b) Segment N1 full rate (left) and half rates for eastern and western flanks (right). Average full and half-spreading rates are given by the slopes of the least squaress fit lines. Note that in both Figures $7 \mathrm{a}$ and $7 \mathrm{~b}$, right-hand diagrams show data for crustal ages of 4.9 to 1.3 $\mathrm{Ma}$; anomaly $1 \mathrm{n}(0 \mathrm{Ma})$ data are not included in the half-rate calculations.

$\mathrm{km} / \mathrm{m} . y$. ., consistent with the current full-spreading rate of $26 \mathrm{~km} / \mathrm{m}$.y. calculated from a global plate motion model [DeMets et al., 1990]. Calculated half spreading rates based on our magnetic data, on both the eastern and western ridge flanks, vary from 13.4 to $12.2 \mathrm{~km} / \mathrm{m}$.y., so there appears to be little long-term asymmetry in spreading.

\section{Gravity Anomaly and Crustal Structure}

\subsection{Gravity Anomaly Analysis}

[26] To examine sub-seafloor density variations, we calculated mantle Bouguer anomalies using the method of Kuo and Forsyth [1988], Prince and Forsyth [1988], and Lin et al. [1990] by subtracting from free-air gravity the predicted gravity effects of seafloor topography and a $6 \mathrm{~km}$ thick model crust (Figure 9). Assumed density of the crustal layer is $2,700 \mathrm{~kg} / \mathrm{m}^{3}$, and that of the underlying mantle is $3,300 \mathrm{~kg} / \mathrm{m}^{3}$, in accordance with values used in previous studies of the MAR [e.g., Kuo and Forsyth, 1988; Lin et al., 1990; Blackman and Forsyth., 1991; Morris and Detrick, 1991; Pariso et al., 1995; Detrick et al., 1995]. To avoid artificial edge effects, we mirrored the grid both east-west and north-south. We further calculated residual mantle Bouguer anomaly (RMBA) by removing theoretically calculated lithospheric 

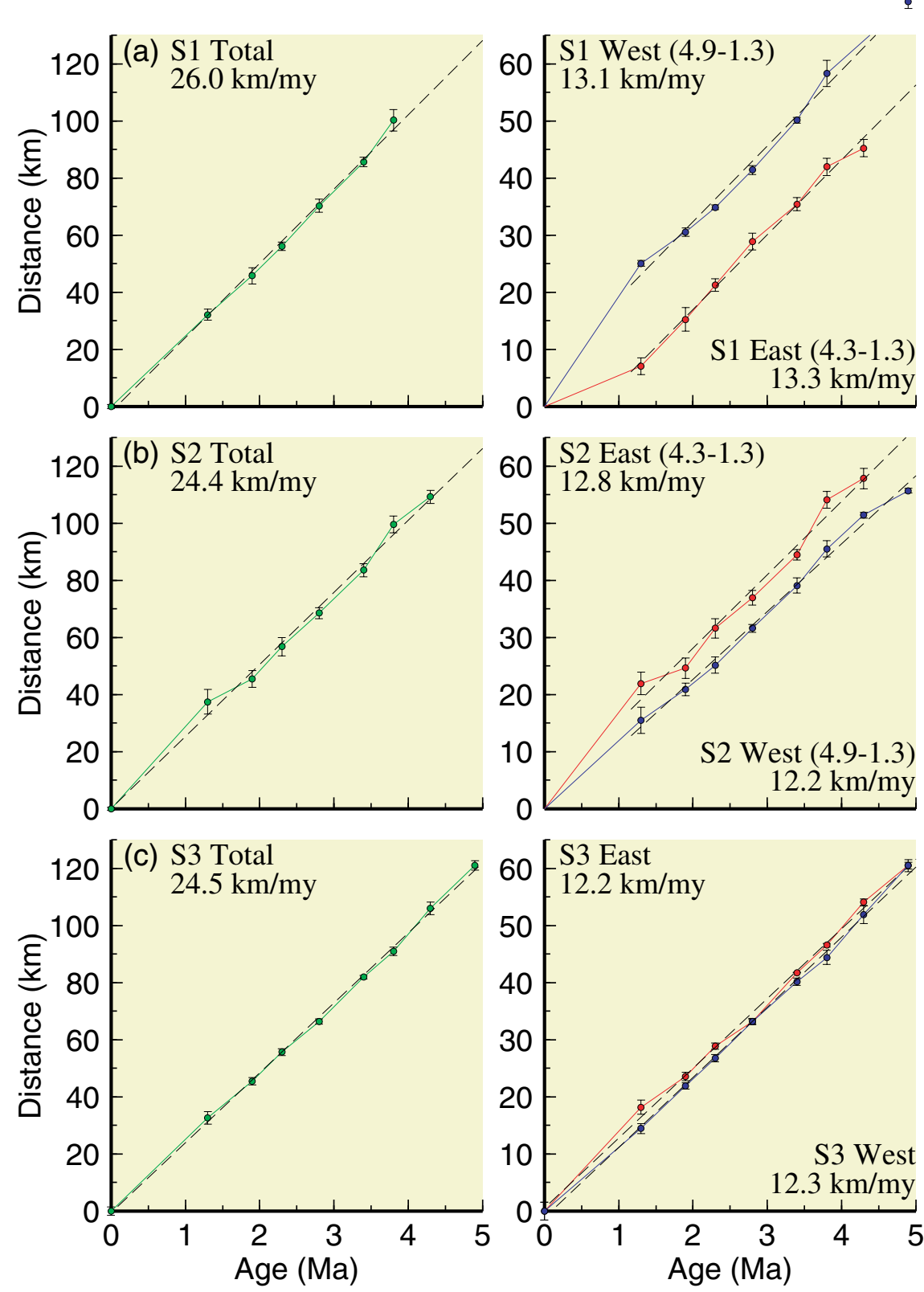

Figure 8. Spreading rate history for segments south of the Fifteen-Twenty Fracture Zone as presented in Figure 7. (a) Segment S1, (b) segment S2, and (c) segment S3. Anomaly 1n (0 Ma) data were not included in the half-rate calculations in segments S1 and S2, although they are included in the calculations for segment S3.

cooling effects from the mantle Bouguer anomaly. The thermal model incorporated both cooling with crustal age and heat transfer across the $200 \mathrm{~km}$ long fracture zone, calculated using the threedimensional passive upwelling model of Phipps Morgan and Forsyth [1988] (Figure 10). Reference asthenospheric temperature was assumed to be $1,320^{\circ} \mathrm{C}$ at a depth of $100 \mathrm{~km}$. The half-spreading
Table 1. Spreading Rates for Each Segment (Unit: km/ m.y.)

\begin{tabular}{cccc}
\hline Segment & Full & Half (West) & Half (East) \\
\hline N2 & $25.1 \pm 0.7$ & $13.0 \pm 0.6^{\mathrm{a}}$ & $12.4 \pm 0.5^{\mathrm{a}}$ \\
N1 & $24.7 \pm 0.7$ & $11.5 \pm 0.5^{\mathrm{a}}$ & $13.4 \pm 0.6^{\mathrm{a}}$ \\
S1 & $26.0 \pm 0.9$ & $13.1 \pm 0.6^{\mathrm{a}}$ & $13.3 \pm 0.6^{\mathrm{a}}$ \\
S2 & $24.4 \pm 0.9$ & $12.2 \pm 0.5^{\mathrm{a}}$ & $12.8 \pm 0.6^{\mathrm{a}}$ \\
S3 & $24.5 \pm 0.7$ & $12.3 \pm 0.5$ & $12.2 \pm 0.5$ \\
\hline
\end{tabular}

${ }^{\mathrm{a}}$ Anomaly $1 \mathrm{n}(0 \mathrm{Ma})$ data are not included in the half-rate calculation. 


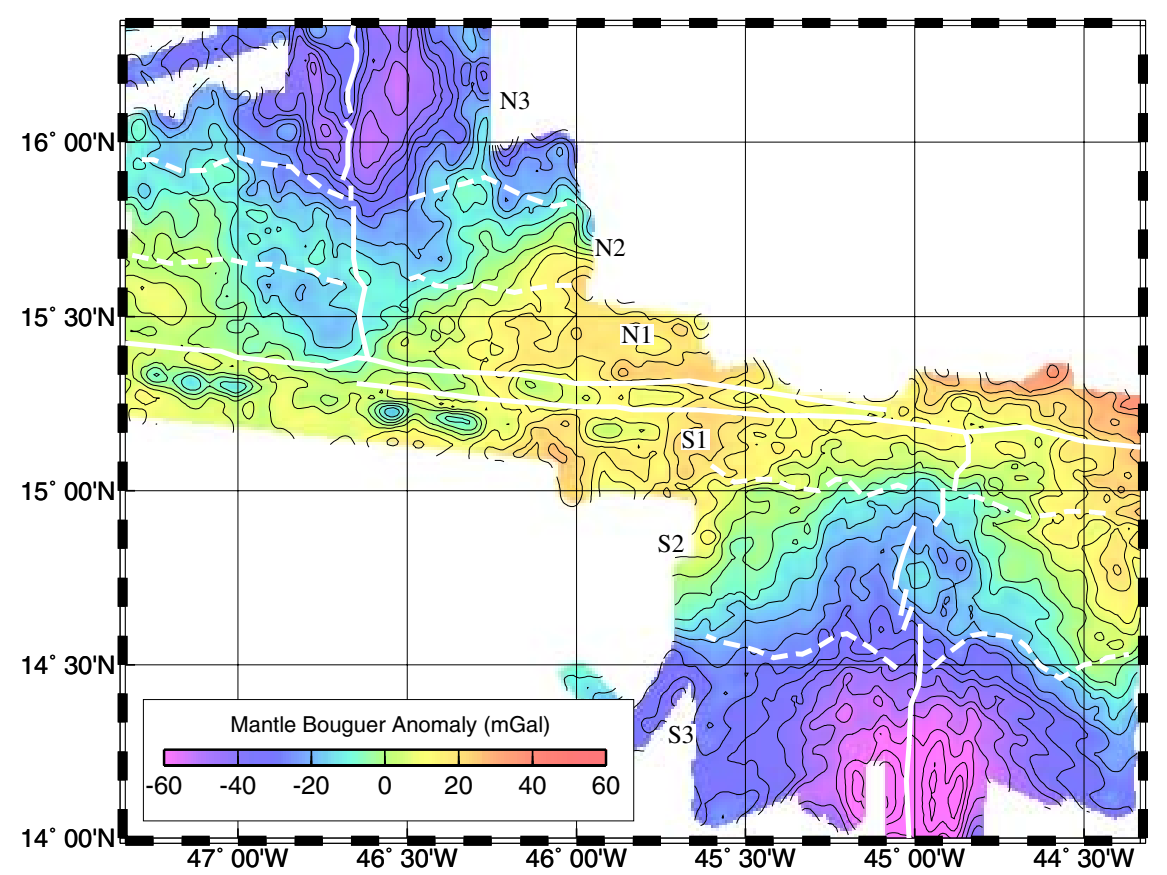

Figure 9. Mantle Bouguer gravity anomaly contoured at $5 \mathrm{mGal}$ intervals. Symbols as in Figure 5.

rate was set to be $12.5 \mathrm{~km} / \mathrm{m}$.y. The resulting temperature field was converted into density variation using a thermal expansion coefficient of 3.4 $\times 10^{-5} /{ }^{\circ} \mathrm{C}$. The ridge axis in this calculation (red line, Figure 10) does not coincide exactly with the present axis as interpreted from morphology and magnetics, but is located centrally between anomalies $1 \mathrm{r}$ on the two flanks. Ignoring the recent shifts

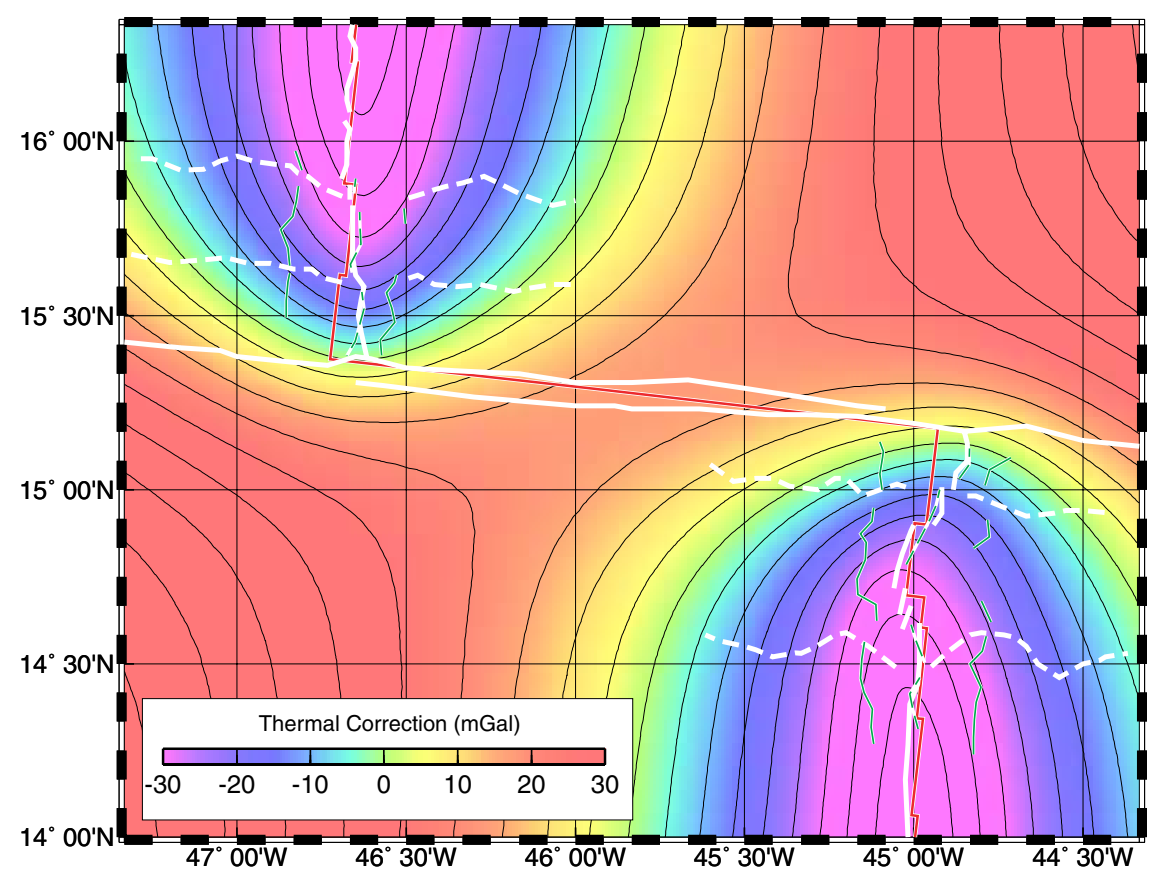

Figure 10. Thermal correction based on 3-D passive mantle upwelling model. Contours are at $5 \mathrm{mGal}$ intervals. A thick red line indicates the location of ridge axes and offsets used in the model calculations. Thin, axis-parallel dashed and solid lines at and near the spreading axis indicate the location of anomalies $1 \mathrm{n}(0 \mathrm{Ma})$ and $1 \mathrm{r}(1.3 \mathrm{Ma})$ defined by crustal magnetization, respectively. Other symbols as in Figure 5. 


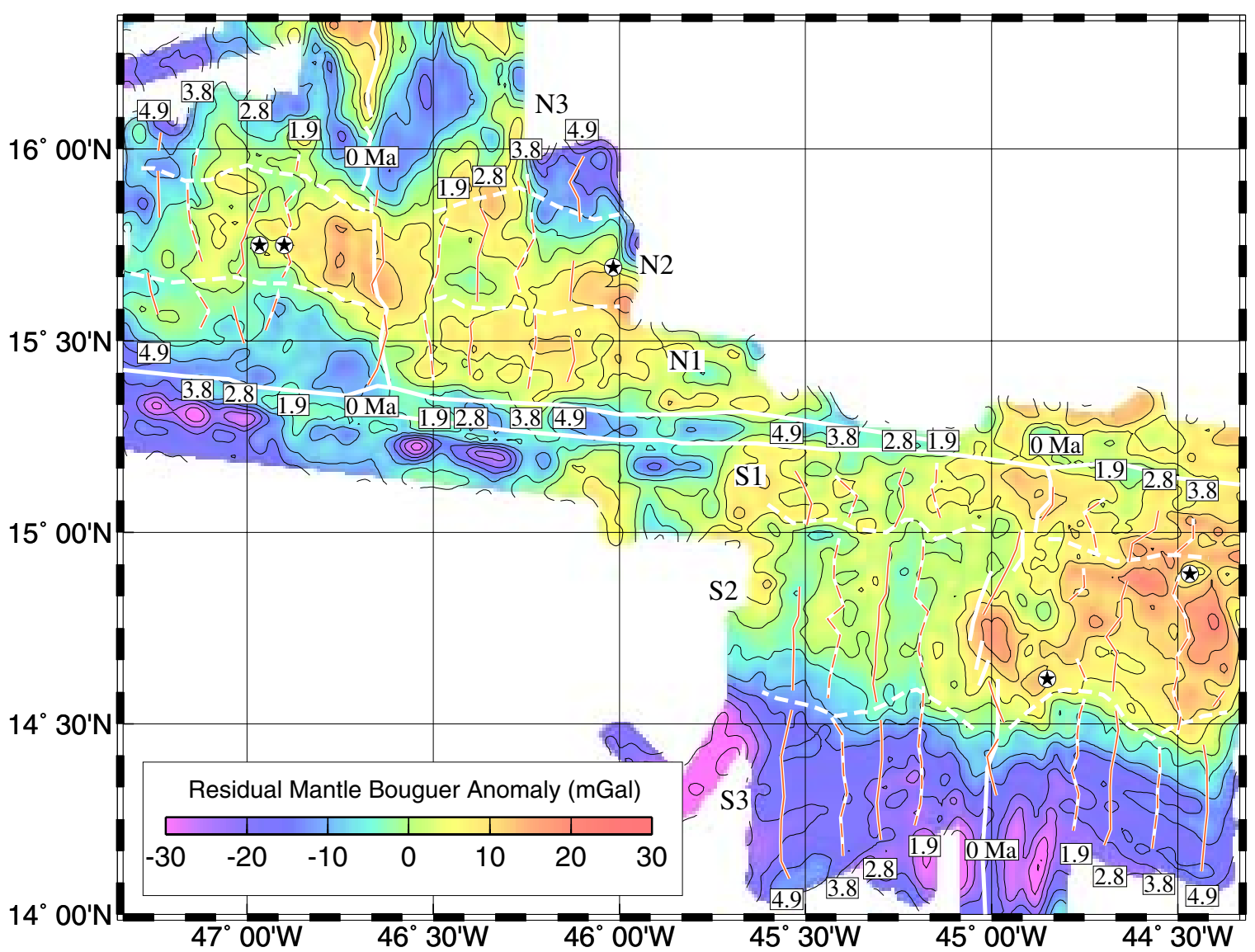

Figure 11. Residual mantle Bouguer anomaly (RMBA). Contours are at $5 \mathrm{mGal}$ intervals. Red solid and dashed lines indicate magnetic isochrons, labeled with ages in Ma. Stars mark crests of identified megamullions. Other symbols as in Figure 5.

in the spreading axis does not introduce significant error in the thermal model. RMBA derived by removing the thermal correction from the mantle Bouguer gravity anomaly is shown in Figure 11. We also calculated a model of relative crustal thickness variation by downward continuing the RMBA (after filtering signals with wavelengths greater than $200 \mathrm{~km}$ and less than $25 \mathrm{~km}$ ) to an assumed mean depth of $6 \mathrm{~km}$ to investigate the amplitude of crustal thickness variations that are required to explain the observed RMBA.

\subsection{Residual Mantle Bouguer Anomaly}

[27] Regionally, areas of elevated RMBA show a good correspondence to areas of irregular topography and magnetic patterns in segments $\mathrm{N} 1, \mathrm{~N} 2$, S1, and S2 (Figure 11). In contrast, a large RMBA low of -20 to $-30 \mathrm{mGal}$ dominates segment S3.
Low RMBA values are also prominent in segment $\mathrm{N} 3$, although the spreading axis north of $16^{\circ} \mathrm{N}$ corresponds with a relative gravity high. The zones of predominantly low RMBA correlate with the long, linear, axis-parallel abyssal hills observed in segment N3 and S3. The gravity patterns suggest that the thickest crust and most robust magma supply appear in segment S3, compared to somewhat reduced and variable magma supply in segment N3 and very limited magmatism in each of the first two segments north and south of the fracture zone (N1, N2, S1, and S2). There is a strong gradient in RMBA of $0.8-1.6 \mathrm{mGal} / \mathrm{km}$ across the segment boundary between segments $\mathrm{S} 2$ and $\mathrm{S} 3$ that has persisted for at least $5 \mathrm{~m} . \mathrm{y}$.

[28] RMBA over segments N1, N2, and S2 is typically asymmetric by about 5-15 mGal between the two ridge flanks. Over segments N1 and S2, the 
RMBA of the eastern flanks is consistently more positive than that of the western flanks out to 5 m.y. off-axis. In segment N2, RMBA on the western flank averages $10 \mathrm{mGal}$ more positive than on the eastern flank out to $\sim 4 \mathrm{Ma}$, whereas the RMBA is low on older crust. These patterns of gravity asymmetry are consistent with bathymetric and magnetic asymmetries. More positive RMBA tends to be associated with elevated topography (Figure 1) and irregular patterns of lower magnetization (Figure 6). An exception is in segment S1, where the western flank is characterized by shallow bathymetry and a high RMBA, but the conjugate, deeper eastern flank also has a high RMBA (Figure 11).

[29] Local, asymmetric RMBA highs are observed on the western and eastern scarps of the axial rift valley walls in segments $\mathrm{N} 2$ and S2, respectively, near $15^{\circ} 40^{\prime} \mathrm{N}$ and $14^{\circ} 45^{\prime} \mathrm{N}$, with values about 15 $\mathrm{mGal}$ more positive than the adjacent crust. These locations coincide with low magnetization and have outcrops of ultramafic rocks (Figures 2, 4, and 6). Off-axis, the observed megamullions which are thought to exhume lower crust and upper mantle rocks are not associated with local RMBA highs, although they occur within areas of generally elevated RMBA (stars, Figure 11). The observation that RMBA highs are not centered over megamullion massifs has also been pointed out by Blackman et al. [1998] and Tucholke et al. [1998] in observations of other portions of the MAR. In each instance, RMBA increases over crust younger than the megamullion toward the spreading axis. And more elevated RMBA correlates over the remaining length of the spreading segment along isochrons, there is no topographic high. The fact that the RMBA is not the most positive over the megamullion would suggest that the megamullion crust is highly altered with an increased degree of serpentinization. If so, the density of the crust would be reduced compared with relatively undeformed rocks underlying surrounding areas.

\subsection{Relative Crustal Thickness}

[30] Calculated crustal thickness variations along selected isochrons are shown in Figure 12. Acrossaxis variations in relative crustal thickness are shown along each segment center north of the fracture zone in Figure 13 and south of the fracture zone in Figure 14. Profiles in segment N3 are not shown because there is little age control from magnetic data (Figure 6). Across the S2/S3 boundary, there is strong off-axis persistence of the contrast in crustal thickness (Figures 12 and 14). Crust in segment S3 averages 1-2.5 km thicker than crust in the other segments out to $5 \mathrm{Ma}$. The regional thickening of crust in segment $\mathrm{S} 3$ shows a strong positive correlation with seafloor depth within the study area. South of $14^{\circ} 20^{\prime} \mathrm{N}$, crustal thickness of the eastern and western flanks is equal, suggesting symmetric magmatic accretion (Figure 12). In contrast, asymmetry in crustal thickness between the eastern and western flanks of segments $\mathrm{N} 1, \mathrm{~N} 2$ and $\mathrm{S} 2$ is on the order of $0.5-1 \mathrm{~km}$, as expected from the RMBA. This thinner crust correlates with elevated topography and disorganized magnetization patterns (Figures 13 and 14).

[31] Near-axis thickening appears in segment N1, where there presently appears to be robust magmatism (Figure 13b). Relative crustal thickness at 1-0 Ma of the other segments N2, S1, and S2 is reduced, nor in segment S3 where thicker crust prevails (Figures 12, 13a, and 14). Apparent crustal thickening could be due to ongoing serpentinization of the shallow mantle, instead of variations in magmatic activity on the ridge axis. Off-axis, the crust of these segments is relatively thicker at $\sim 3$ $2 \mathrm{Ma}$ and thinner at $\sim 5-4 \mathrm{Ma}$. If this thickening and thinning can be attributed to spreading dominated by alternating episodes of tectonic extension and magmatism, the observations suggest a cycle that lasts about $\sim 3-4$ m.y.

\section{Discussion}

\subsection{Ridge Tectonism and Magmatism}

[32] Morphology, magnetization, and gravity are consistent in showing a remarkable contrast in apparent crustal thickness and tectonism between the two pairs of ridge segments that are adjacent to the Fifteen-Twenty Fracture Zone, compared to segments farther from the fracture zone (Figures 1,6 , and 11). Morphology and gravity data indicate that segments N1, N2, S1, and S2 have thin and 

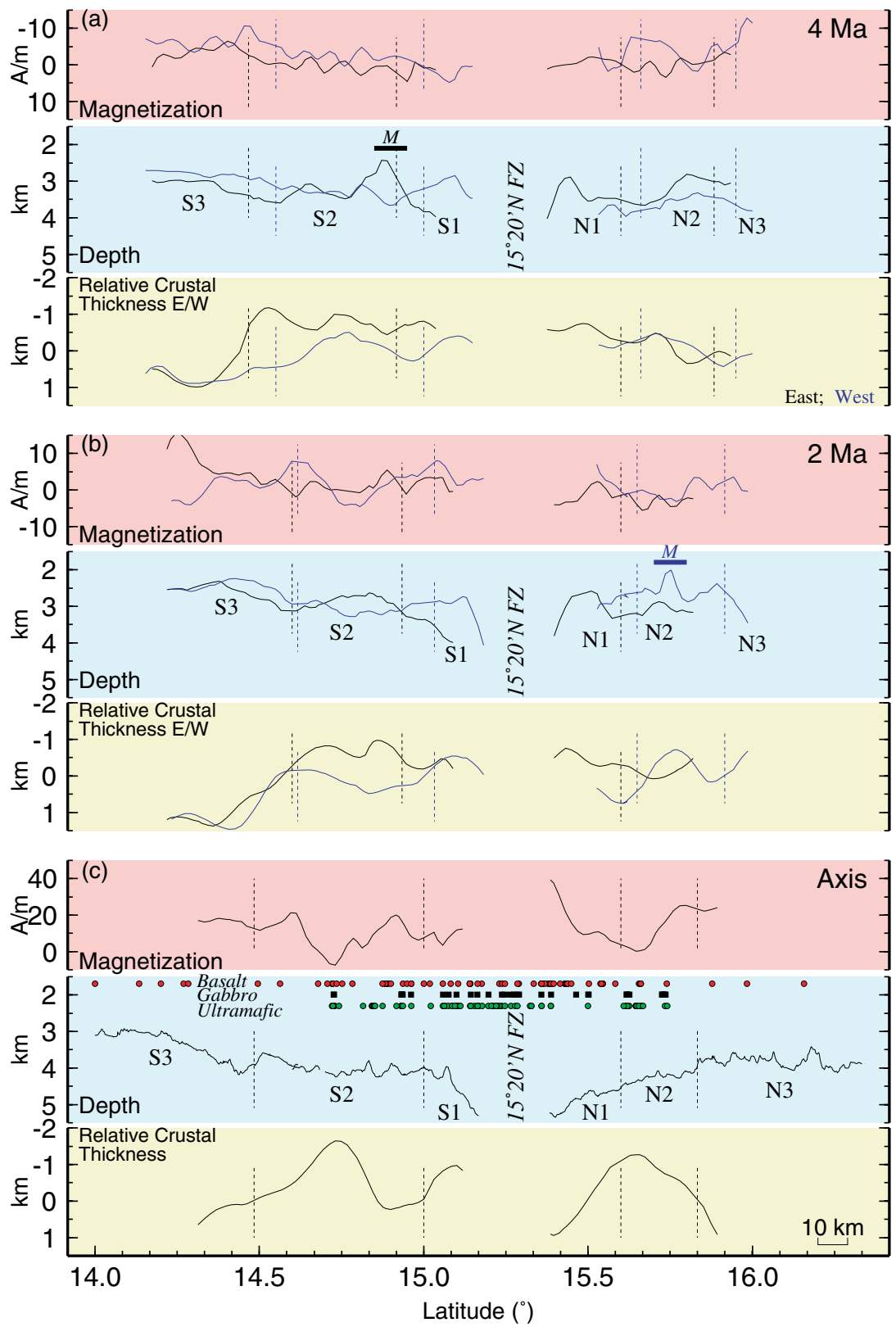

Figure 12. Along-isochron profiles of magnetization, seafloor depth, and relative crustal thickness calculated from RMBA at three crustal ages. For each panel the magnetization is shown on top, the depth is shown in the middle, and the relative crustal thickness is shown at the bottom. (a) Solid lines are averages within a $5 \mathrm{~km}$ wide stripe centered at anomaly $2 \mathrm{Ar}$ ( $\sim 4 \mathrm{Ma}$ isochron). Black and blue lines are data for the eastern and western flanks, respectively. Correspondingly colored vertical dashed lines indicate locations of segment boundaries on the two ridge flanks. M indicates megamullion. (b) Averaged profiles within a $5 \mathrm{~km}$ wide stripe centered at anomaly 2 ( 2 Ma isochron). Black and blue lines are for eastern and western flanks, respectively. (c) Seafloor axial depth profile along the median valley, with average crustal thickness in a $5 \mathrm{~km}$ wide stripe centered at anomaly $1 \mathrm{n}$ ( $0 \mathrm{Ma}$ isochron). Locations of rock samples from up to $20 \mathrm{~km}$ off-axis are projected to the axis.

highly tectonized crust, whereas segment S3 has normal thickness crust and regular faulting that has created linear abyssal hills. Segment N3 also has more normal structure than the segments nearer the fracture zone, but it is not as uniformly developed as segment S3. This large scale pattern is consistent with available seafloor sample data, which demonstrate that gabbros and serpentinized 


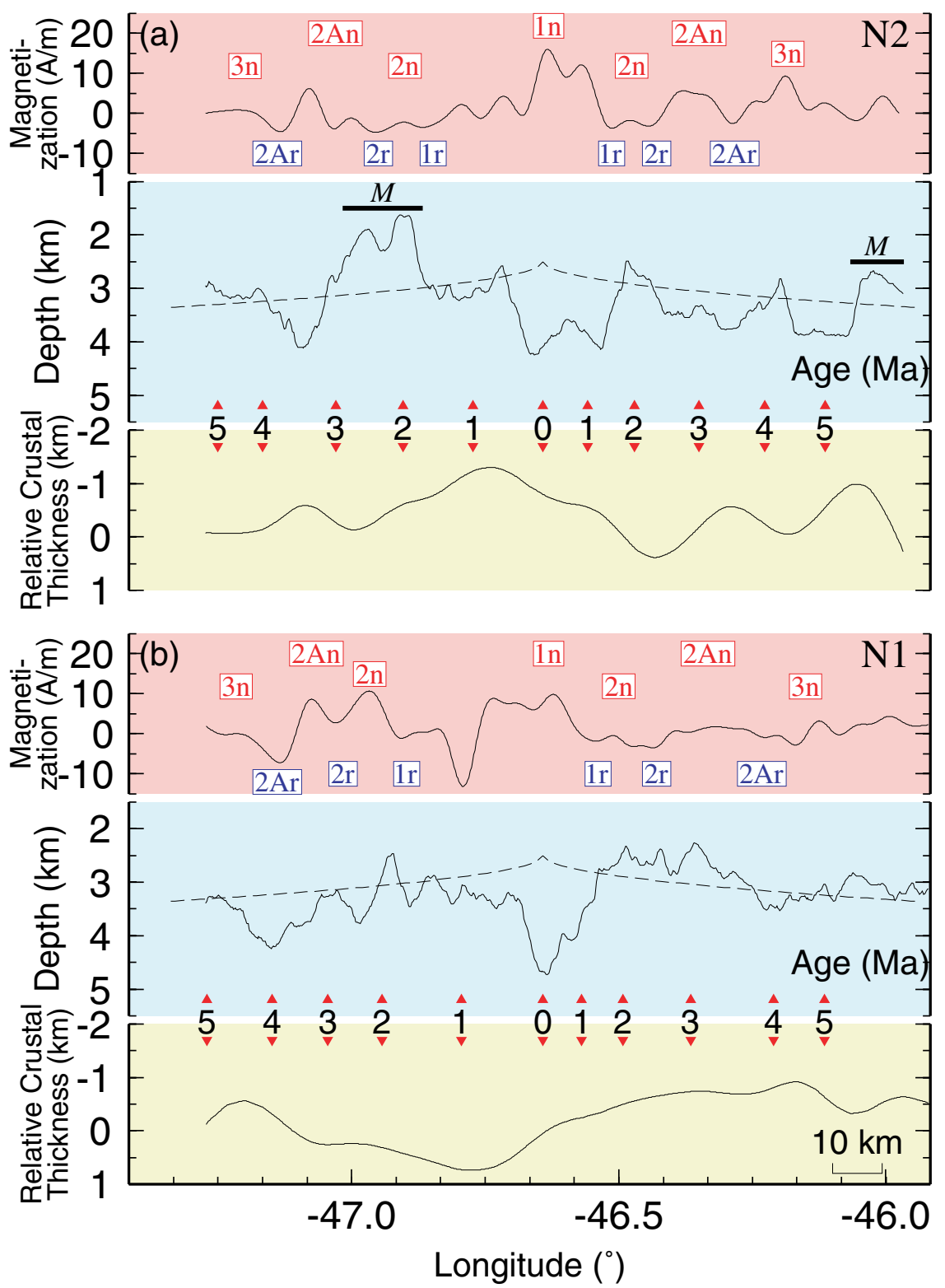

Figure 13. Cross-axis profiles of segments N1 and N2 north of the Fifteen-Twenty Fracture Zone, located along segment centers. (a) Segment N2. Magnetization profile is shown at top. Interpreted magnetic anomalies are labeled. Seafloor depth profile is shown in the middle, and average relative crustal thickness within a $5 \mathrm{~km}$ wide stripe is shown at bottom. Dashed line shows predicted seafloor subsidence with age based on Parsons and Sclater [1977]. Triangles mark average crustal ages in Ma. M indicates megamullion. (b) Magnetization, seafloor depth profile, and averaged relative crustal thickness in segment N1.

peridotites commonly crop out in segments N1, $\mathrm{N} 2$, S1, and S2, whereas only basalts have been recovered thus far from segments $\mathrm{N} 3$ and S3 (Figures 2 and 4). The sample data and the reduced amplitude, irregular magnetic patterns in the former segments also indicate that the thinness of the crust is explained in large part by a thin or missing extrusive basalt layer.
[33] The interpretation that high values of RMBA indicate thin magmatic crust or high-density lower crust or upper mantle at shallow sub-seafloor depths is confirmed by recent seismic refraction experiments along the rift valley through segments N1N3 [Detrick and Collins, 1998; J. A. Collins and R. B. Detrick, personal communication, 2002]. The seismic data were obtained using both the Near 

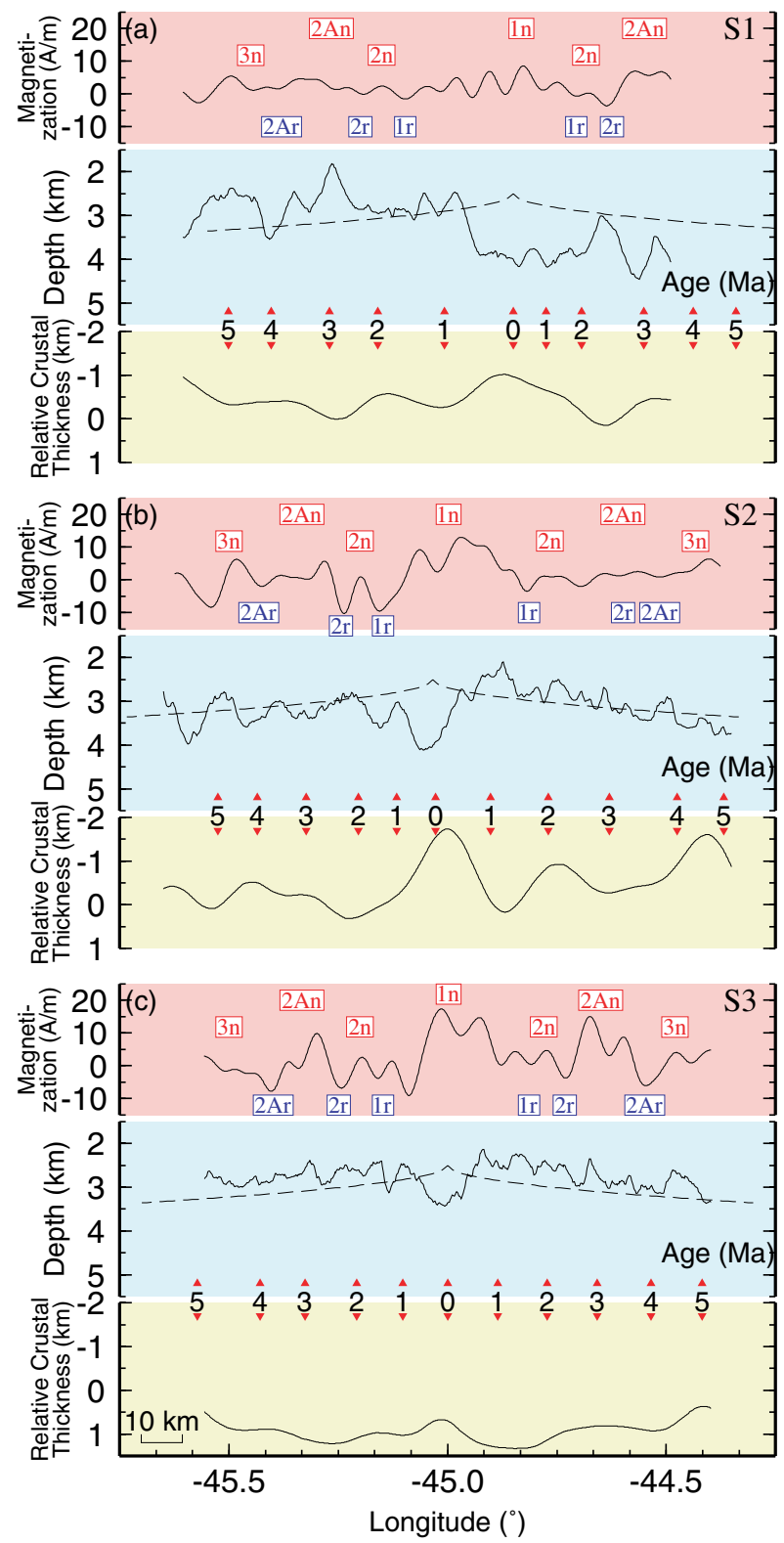

Figure 14. Cross-axis profiles of segments S1, S2, and S3 south of the Fifteen-Twenty Fracture Zone, located along segment centers and illustrated as in Figure 13. (a) Magnetization, seafloor depth profile, and averaged relative crustal thickness in segment S1. (b) Magnetization, seafloor depth profile, and averaged relative crustal thickness in segment S2. M indicates megamullion. (c) Magnetization, seafloor depth profile, and averaged relative crustal thickness in segment S3.

Ocean Bottom Explosives Launcher (NOBEL) and airgun profiling to ocean bottom seismometers, and they show marked crustal thinning in the area of the RMBA high between $15^{\circ} 35^{\prime} \mathrm{N}$ and $15^{\circ} 40^{\prime} \mathrm{N}$ (Figure 12). Below a strong velocity gradient in the upper $\sim 2 \mathrm{~km}$ of seafloor, velocities increase gradually over the next $3-4 \mathrm{~km}$ from $\sim 7.2$ to $8 \mathrm{~km} / \mathrm{s}$. The smooth velocity gradient structure with no apparent velocity jumps is very different from that of a typical igneous crustal section, which may indicate decreasing serpentinization with depth in mantle rocks.

[34] Our geophysical data, which suggest thin crust in segments N2, N1, S1, and S2 near the fracture zone, appear to be at odds with geochemical data on peridotites and basalts dredged along the rift axis [Bonatti et al., 1992; Dosso et al., 1993]. The geochemical data indicate that the peridotites are strongly depleted and the basalts are enriched, consistent with a "hot spot" or "wet-spot" melting anomaly in the underlying asthenosphere [Bonatti et al., 1992] but inconsistent with the paucity of basalts in the rift valley. If upwelling mantle peridotite begins to cool conductively and stops melting at depths of $\sim 20-30 \mathrm{~km}$ beneath slow spreading ridges [e.g., Sleep, 1975; Reid and Jackson, 1981], peridotites exposed today at the seafloor ceased to melt at $\sim 2-3$ Ma given a halfspreading rate $\sim 10 \mathrm{~km} / \mathrm{m}$.y. Thus, the exceptionally depleted peridotites in the vicinity of the Fifteen-Twenty Fracture Zone might be complemented by exceptionally thick crust in seafloor $\sim 2-3$ Ma old. Indeed, our data show that the thickness of crust formed at $\sim 2-3 \mathrm{Ma}$ is greater than at present (Figures 13 and 14). However, the peridotite samples from the Fifteen-Twenty area are the most depleted known along the MAR (compare data in, e.g., Dick et al. [1984] and Bonatti et al. [1992]. If this depletion is associated with a single stage of mantle melting to produce normal mid-ocean ridge basalt, this region should be associated with exceptionally thick crust. However, there is no such crust in our study area, except perhaps toward the southern segment S3.

[35] A possible explanation is that mantle below this area is heterogeneous and that the melt supply to the rift axis therefore has been highly non-uniform. Under these conditions, it is possible that the depleted mantle presently exposed in the rift valley lost its melt more than 5 m.y. ago (from depths $>60$ $\mathrm{km}$ at observed spreading rates); subsequently upwelling mantle was relatively infertile and pro- 
duced little melt, and only recently has upwelling of deeper, more fertile mantle again produced melts that have risen through the asthenosphere to be deposited in the floor of the rift valley. The sharp transition in relative crustal thickness between segments $\mathrm{S} 2$ and $\mathrm{S} 3$ provides evidence that significant changes in mantle fertility occur over short horizontal distances in this region, so it is not unlikely that similar changes occur in the vertical dimension.

\subsection{Asymmetry of Crustal Structure Within Segments}

[36] The asymmetry in morphology and geophysical characteristics between opposing ridge flanks in segment N2 and extending south through segment S2 is very similar to that observed between inside and outside corner crust near transform and non-transform offsets [Tucholke and Lin, 1994]. The inside/outside corner asymmetry is attributed to longevity of faults that dip from the inside corner into the rift valley, compared with more ephemeral inward-dipping faults on the outside corner. Thus, deep lithospheric sections are exhumed in inside corner footwall blocks, while most magma supplied to the rift is deposited in the outside corner hanging walls. Compared to outside corner crust, inside corner crust is elevated, has irregular faults and topography, and has high RMBA.

[37] These are the kinds of asymmetries we observe in the four spreading segments near the Fifteen-Twenty Fracture Zone, and we suggest that a persistent polarity of major faults at the edge of the rift valley throughout each segment is responsible. Interpreted in the context of the inside/outside corner model, the history of offsets between spreading segments would be as depicted in Figure 15. In general, the actual offsets of the non-transform discontinuities are so small that their positions and senses of offset cannot be resolved from the magnetic anomaly pattern (Figure 6). The important point is that irrespective of offset, individual segments appear to have behaved coherently in maintaining polarity of major faults for long periods of time.

[38] Detachment faults are important tectonic features that bring deep lithospheric sections to shal- low levels and causes morphological asymmetry across axis [e.g., Karson et al., 1987; Cannat et al., 1995; Karson and Lawrence, 1997]. The formation of oceanic crustal detachment faults is hypothesized to be promoted by tectonic extension due to low magma supply to the ridge axis. Lower crust and upper mantle are exhumed by unroofing of the footwall block along the detachment, while most magma supplied to the upper crust is in the hanging wall. There is a strong tendency for the footwall of large faults to develop in inside corner crust based on studies from other portions of slowspreading ridges [Tucholke and Lin, 1994]. The detachment fault hypothesis suggests that as oceanic crust forms at a slow-spreading ridge axis, upper crust is preferentially transported to outside corners, and lower crust and upper mantle are exposed at inside corners [e.g., Buck, 1988; Wernicke and Axen, 1988].

[39] Cannat et al. [1997] suggested that an asymmetrical fault model is not applicable to the region of the Fifteen-Twenty Fracture Zone because ultramafic rocks are locally exposed on both ridge flanks. Instead, they proposed that exposure of ultramafic rocks on both flanks can be accomplished by frequent changes of faulting polarity in the axial region. Ultramafic rocks are envisioned to have been uplifted into the footwall of the fault that bounds the outside corner rift wall. As spreading proceeds, there is a need for a new fault to initiate in the axial valley floor. This new fault faces in the opposite direction, and exposes ultramafic rocks on the opposite side of the ridge axis.

[40] This is certainly a possibility in segment S1 where both inside and outside corner crust appear to be thin for distances extending well off-axis (Figure 11). However, it is also possible that faulting is asymmetrical. If there is in fact very little crust being formed in segment $\mathrm{S} 1$ because of very limited melt supply, there is no practical way to make a distinction between these possibilities from geophysical data, and much denser seafloor sampling will be required to test the alternatives. In the other ridge segments $(\mathrm{N} 1, \mathrm{~N} 2$, and S2), there are clear differences in relative crustal thickness between ridge flanks, and the ridge flanks are persistent in their asymmetric patterns for at least 


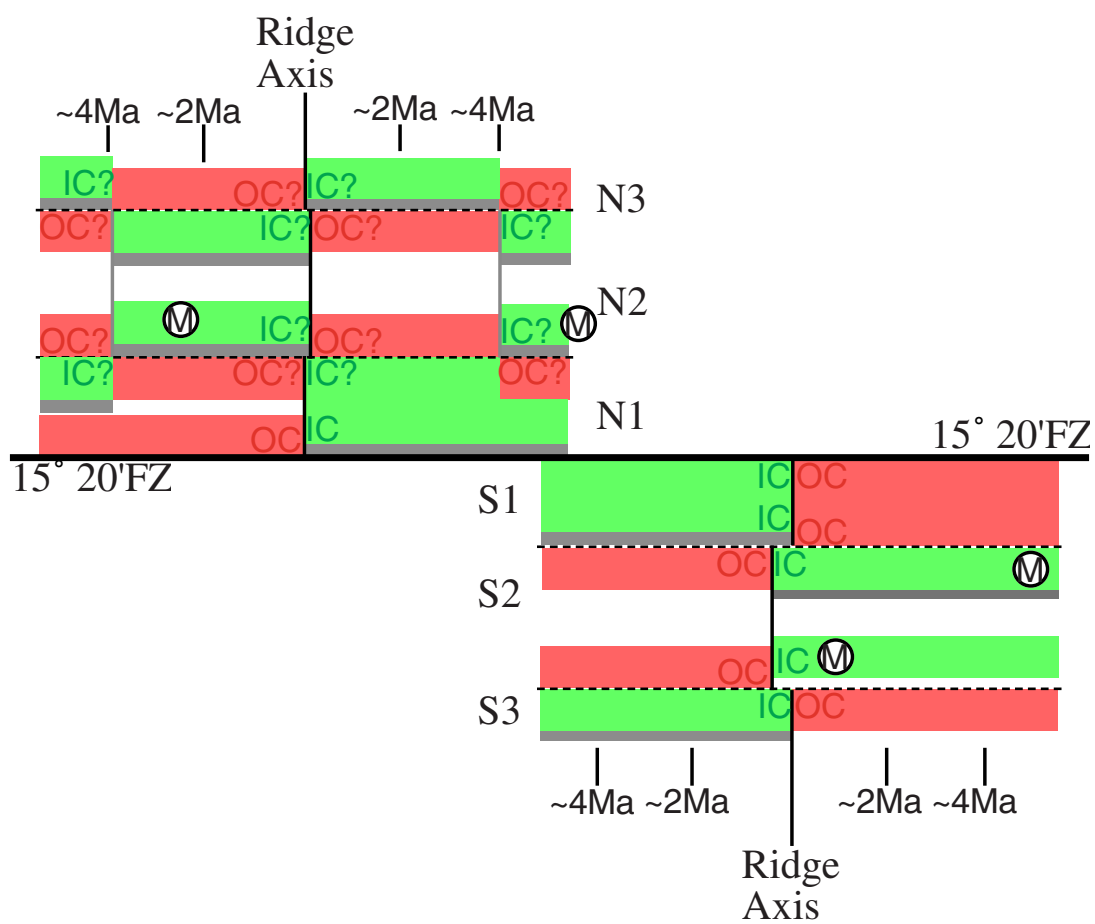

Figure 15. Schematic depiction of ridge geometry around the Fifteen-Twenty Fracture Zone. IC indicates inside corner, and OC indicates outside corner. Green areas show inside corner crust and red areas show outside corner crust, respectively. $\mathrm{M}$ indicates megamullion. In segment N2, a reversal in offset of segment boundaries is inferred to have occurred at $\sim 4 \mathrm{Ma}$, changing the inside/outside corner configuration.

a few million years (Figures 13 and 14). This observation supports the idea of long-term asymmetry in dominant polarity of faults.

\subsection{Development of Megamullions on Ridge Flanks}

[41] Megamullions have been interpreted to represent rotated footwalls of long-lived normal faults, i.e., detachment faults, with mullions that form corrugations on the exposed fault surface striking parallel to direction of displacement [Tucholke et al., 1996, 1998; Cann et al., 1997]. Such longlived faults tend to occur at inside corners, and the vast majority of known megamullions are observed in these settings [Tucholke et al., 1998]. This appears also to be the case for the megamullions observed in the study area.

[42] The two megamullions within segment S2 are both on the eastern flank, in crust that the morphological and geophysical data suggest inside corner crust (Figure 15). The older megamullion ( $\sim 4 \mathrm{Ma}$;
Figure 3d) is broken by a west-facing scarp at its western edge and may have been terminated by formation of new high-angle normal fault that cut into the detachment footwall. The younger megamullion is in the crest of the rift mountains (Figure $3 \mathrm{c}$ ) and is not well developed in terms of the dome shape that is normally exhibited. It is uncertain whether the detachment fault that formed this feature is still active or has been replaced by a younger fault closer to the rift axis.

[43] Within segment N2, megamullions appear on both flanks of the ridge axis (Figures 2 and 13a). The eastern flank megamullion is in crust older than $5 \mathrm{Ma}$, while the western flank feature is in $\sim 3-2$ Ma crust. According to the inside/outside corner model suggested by the geophysical data (Figure 15), both are in inside corner crust. However, there are two alternate models that could explain this. In one, the older megamullion, presently on the eastern flank, was formed on the western flank by an eastdipping detachment in an inside corner setting, with relatively large-offset right-stepping southern and 

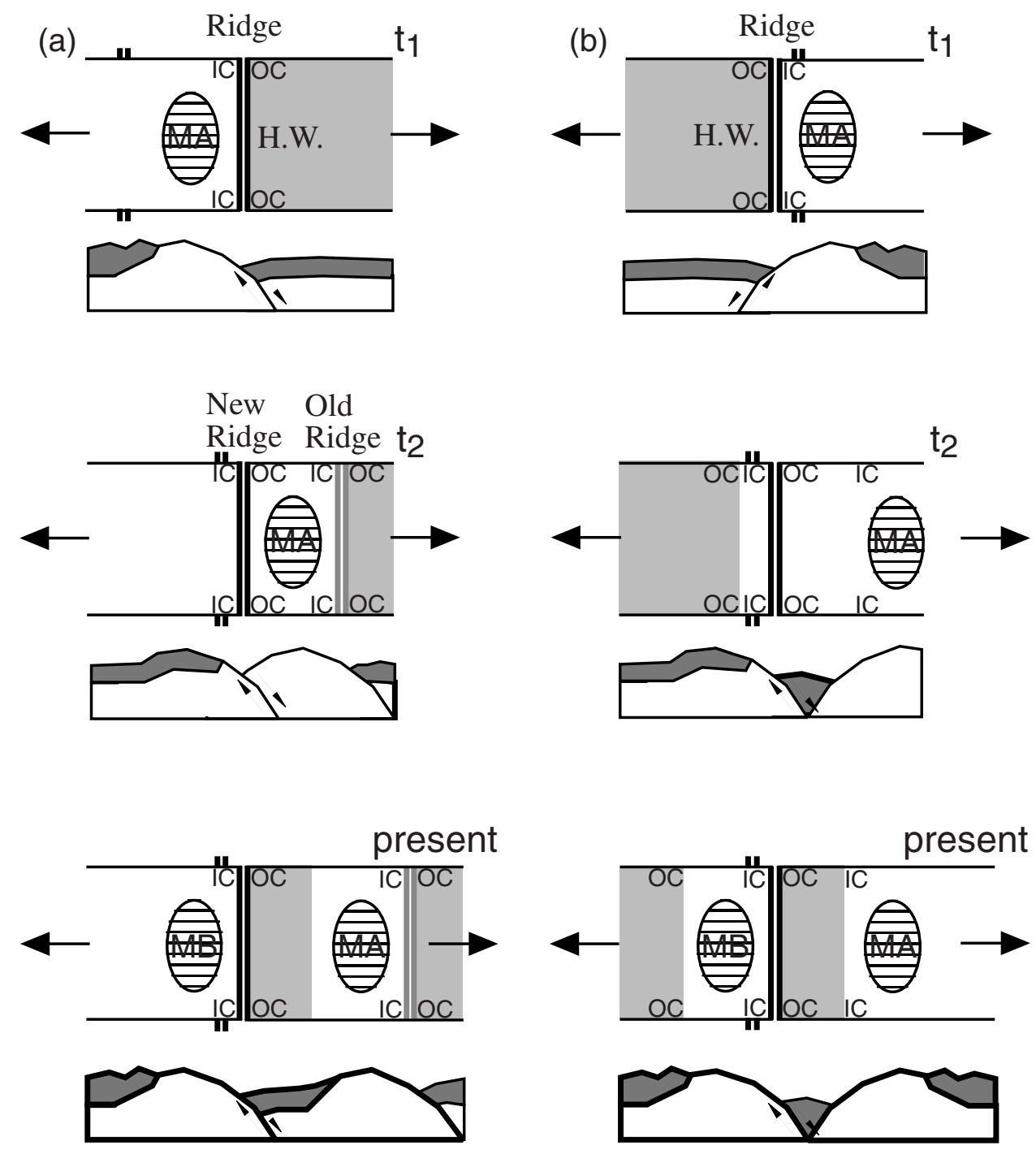

Figure 16. Schematic models showing two possible origins of the megamullions on the eastern and western flanks of segment N2. At the top of each panel is a map view of the segment and at the bottom is across-sectional view through the center of the segment. In the map views, shaded sections indicate upper crust. MA is the older, eastern flank megamullion, MB is the younger, western flank megamullion, H.W. is the hanging wall, and IC and OC locate inside and outside corner crust dictated by geometry of ridge offsets. (a) The eastern flank megamullion is formed in an inside corner position on the western flank, then it is transferred to the eastern flank by a ridge jump before the younger, western flank megamullion is formed. (b) The eastern flank megamullion is formed at an inside corner position on the eastern flank of the spreading axis; ridge offsets and polarity of major faults bounding the axial valley then reverse, and the western flank megamullion is subsequently formed.

left-stepping northern segment boundaries (Figure 16a). The megamullion (MA) was then transferred to the eastern flank by a westward ridge jump which shortened the boundary offsets but did not change the inside/outside corner configuration. Such a ridge jump would have to occur no later than anomaly $3 n-$ old (4.9 Ma) because there is no significant offset of isochrons at the segment boundary in younger crust
(Figure 6). The second megamullion (MB) subsequently formed on the western flank in the same inside corner position, beginning at about $3 \mathrm{Ma}$. This would result in a configuration of inside/outside corner crust slightly different from that shown in Figure 15 inside or outside corner crust as presently observed near-axis would continue out to or beyond the edge of the survey area in the southern part of 
segment N3 and the northern part of segment N1 on both flanks, and in the southern and northern parts of segment $\mathrm{N} 2$ on the western flank.

[44] An alternate possibility requires the detachment fault at the ridge axis to reverse its direction of dip [Cannat and Casey, 1995; Cannat et al., 1997; Casey and Fujiwara, 2001]. The older megamullion (MA) was formed on the eastern flank of the MAR by a west-dipping detachment fault between a left-stepping offset at the southern segment boundary and a right-stepping offset at the northern boundary, i.e., in an inside corner position (Figure 16b). This fault was abandoned so that megamullion formation stopped, and the fault was replaced by an east-dipping detachment that eventually led to formation of the second megamullion (MB) on the western flank. This scenario would result in the kind of inside/outside corner distribution shown north of the Fifteen-Twenty Fracture Zone in Figure 15. It might be caused by the spreading axis in segment $\mathrm{N} 2$ migrating or jumping eastward so that offsets at segment boundaries were reversed and eastern flank inside corners were transformed to outside corners.

[45] We presently cannot distinguish between these models. The geophysical character of crust at the outer limits of the segment N3/N2 and N2/N1 boundaries is not diagnostic of either inside or outside corner crust, and our survey does not extend far enough off-axis to determine whether or not a westward ridge jump shortened once-longer offsets at the boundaries of segment N2. Additional survey over crust an additional 2-3 m.y. off-axis will be needed to resolve this question.

\section{Conclusions}

[46] We conducted a multibeam bathymetry, magnetic, and gravity survey of the Mid-Atlantic Ridge to 5 m.y. off-axis around the Fifteen-Twenty Fracture Zone between $14^{\circ} \mathrm{N}$ and $16^{\circ} \mathrm{N}$. Our analysis of these data yielded the following results:

1. We identified two complete spreading segments plus portions of a third segment on each side of the fracture zone. Ridge flank crust in the four segments near the fracture zone is characterized by irregular and blocky topography that is interpreted to be created by irregular fault patterns. These segments show strong bathymetric asymmetry across-axis, with average depth differences of 500 to $1,000 \mathrm{~m}$. In contrast, the segments at the northernmost and southernmost of the study area are associated with long and linear abyssal hills formed by more closely spaced faults with limited throw, and ridge flank depths are symmetrical about the spreading axis.

2. Magnetic anomalies out to anomaly 3n (4.9 Ma) were identified. Average full-spreading rates have been $25 \mathrm{~km} / \mathrm{m}$.y. for the last 5 m.y. During the last $1 \mathrm{~m} . \mathrm{y}$., there are spreading asymmetries of 30 $70 \%$ in the four tectonically dominated segments surrounding the fracture zone. These asymmetries probably are caused by asymmetric tectonic extension, ridge jumps, or combinations of the two. The ridge segment south of $14^{\circ} 30^{\prime} \mathrm{N}$ has been spreading symmetrically for the past 5 m.y.

3. Magnetic anomalies are well lineated, high amplitude, and symmetrical in the spreading segment south of $14^{\circ} 30^{\prime} \mathrm{N}$, consistent with this segment being characterized by normal magmatic accretion. Relatively low amplitude, irregular to discontinuous magnetic lineations in the four segments near the fracture zone probably reflect limited thickness of basaltic crust and tectonic disruption of this extrusive layer over the past $5 \mathrm{~m}$.y. The low amplitude, irregular magnetic patterns also are consistently associated with elevated, irregular seafloor topography.

4. Residual mantle Bouguer anomaly (RMBA) highs show a good correspondence to areas with irregular seafloor morphology with abyssal hill lineation oblique to the ridge axis. RMBA are high, with amplitudes of $0-20 \mathrm{mGal}$, over the four segments flanking the fracture zone, implying relatively thin crust due to limited magma supply. The across axis asymmetry in RMBA amounts to 5-10 mGal, corresponding to $0.5-1 \mathrm{~km}$ in crustal thickness over the segments near the fracture zone. Where such asymmetry is observed, relatively large positive RMBA is consistently observed over relatively elevated crust, and smaller RMBA is observed over conjugate, deeper crust. RMBA lows of about $-20 \mathrm{mGal}$ extend uniformly over segment south of $14^{\circ} 30^{\prime} \mathrm{N}$, indicating that it is a magmatically robust segment with thick crust. 
5. Megamullions are found in the off-axis crust of two of the tectonically dominated spreading segments. The second segment north of the fracture zone has megamullions on both flanks, one in $\sim 5$ Ma crust on the eastern flank and one in $\sim 3-2 \mathrm{Ma}$ crust on the western flank. The east-flank megamullion may have been formed previously on the western flank by an east-dipping normal fault, then transferred to the eastern flank by a westward ridge jump. Alternately, it may have been formed on the eastern flank by a west-dipping fault, with subsequent reverse of fault polarity to form the western flank megamullion.

6. Limited magma supply appears to have characterized the four spreading segments near the fracture zone over the past $\sim 5 \mathrm{~m}$.y. This appears to be inconsistent with geochemical data from depleted peridotites and enriched basalts on-axis which indicate the area overlies a melting anomaly in the mantle. We suggest that this can be explained by significant vertical heterogeneity in the rising asthenospheric mantle at a scale of $\geq 60 \mathrm{~km}$, and a corresponding large variation in melt supply to the spreading axis. Thus, the enriched basalts presently found at the ridge axis may be from recently tapped fertile mantle; they have been emplaced over peridotites that were depleted at depth more than 5 m.y. ago but that were only lately exhumed in the rift valley by tectonic extension. Rising, relatively infertile mantle in the intervening period provided only a limited supply of melt to these spreading segments, and they consequently have been dominated by tectonic extension for the past 5 m.y.

\section{Acknowledgments}

[47] We are grateful to the YK98-05 shipboard scientific party, M. Joshima, A. Takeuchi, G. M. Ceuleneer, and M. G. Braun for collaboration at sea and in scientific discussions, and to H. Kinoshita and R. S. Detrick for their participation in planning the survey. We thank the officers and crew of $\mathrm{R} / \mathrm{V}$ Yokosuka and submersible Shinkai 6500 for outstanding professionalism and dedication that made the cruise successful. We are also indebted to S. Kanda for his invaluable help at sea. We thank A. Hosford for providing preprints of her work and M. D. Behn for help with gravity processing programs. We thank J. Escartín for providing bathymetric and gravity data collected onboard the N/O Atalante. We thank D. W. Forsyth, D. K. Blackman, and an anonymous reviewer for their helpful comments in improving the manuscript. The
GMT software [Wessel and Smith, 1995] was extensively used in this study. This work was completed while T. Fujiwara was a Guest Investigator at Woods Hole Oceanographic Institution with funding from Japan Marine Science and Technology Center (JAMSTEC), National Science Foundation, and the JAMSTEC Research Overseas Program. J. Lin's contributions to this research were supported by NSF Grant OCE-9811924. B. E. Tucholke's contributions were supported by NSF Grant OCE-9503561 and by the Andrew W. Mellon Endowment Fund for Innovative Research and the Henry Bryant Bigelow Chair at Woods Hole Oceanographic Institution. Contribution No. 10,702 of Woods Hole Oceanographic Institution.

\section{References}

Blackman, D. K., and D. W. Forsyth, Isostatic compensation of tectonic features of the Mid-Atlantic Ridge: $25-27^{\circ} 30^{\prime} \mathrm{S}$, J. Geophys. Res., 96, 11,741-11,758, 1991.

Blackman, D. K., J. R. Cann, B. Janssen, and D. K. Smith, Origin of extensional core complexes: Evidence from the Mid-Atlantic Ridge at Atlantis Fracture Zone, J. Geophys. Res., 103, 21,315-21,333, 1998.

Bonatti, E., A. Peyve, P. Kepezhinskas, N. Kurentsova, M. Seyler, S. Skolotnev, and G. Udintsev, Upper mantle heterogeneity below the Mid-Atlantic Ridge, $0^{\circ}-15^{\circ} \mathrm{N}$, J. Geophys. Res., 97, 4461-4476, 1992.

Bougault, H., L. Dmitriev, J.-G. Schilling, A. Sobolev, J.-L. Joron, and H. D. Needham, Mantle heterogeneity from trace elements: Mid-Atlantic Ridge triple junction near $14^{\circ} \mathrm{N}$, Earth Planet. Sci. Lett., 88, 27-36, 1988.

Bougault, H., J.-L. Charlou, Y. Fouquet, H. D. Needham, N. Vaslet, P. Appriou, P. J. Baptiste, P. A. Rona, L. Dmitriev, and S. Silantiev, Fast and slow spreading ridges: Structure and hydrothermal activity, ultramafic topographic highs, and $\mathrm{CH}_{4}$ output, J. Geophys. Res., 98, 9643-9651, 1993.

Buchanan, S. K., R. A. Scrutton, R. A. Edwards, and R. B. Whitmarsh, Marine magnetic data processing in equatorial regions off Ghana, Geophys. J. Int., 125, 123-131, 1996.

Buck, W. R., Flexural rotation of normal faults, Tectonics, 7 , 959-973, 1988.

Cande, S. C., and D. V. Kent, Revised calibration of the geomagnetic polarity timescale for the late Cretaceous and Cenozoic, J. Geophys. Res., 100, 6093-6095, 1995.

Cann, J. R., D. K. Blackman, D. K. Smith, E. McAllister, B. Janssen, S. Mello, E. Avgerinos, A. R. Pascoe, and J. Escartín, Corrugated slip surfaces formed at ridge-transform intersections on the Mid-Atlantic Ridge, Nature, 385 , 329-332, 1997.

Cannat, M., and J. F. Casey, An ultramafic lift at the MidAtlantic Ridge: Successive stages of magmatism in serpentinized peridotites from the $15^{\circ} \mathrm{N}$ region, in Mantle and Lower Crust Exposed in Oceanic Ridges and in Ophiolites, edited by R. L. M. Vissers and A. Nicolas, pp. 5-34, Kluwer Acad., Norwell, Mass., 1995.

Cannat, M., D. Bideau, and H. Bougault, Serpentinized peridotites and gabbros in the Mid-Atlantic Ridge axial valley at $15^{\circ} 37^{\prime} \mathrm{N}$ and $16^{\circ} 52^{\prime} \mathrm{N}$, Earth Planet. Sci. Lett., 109, 87-106, 1992. 
Cannat, M., et al., Thin crust, ultramafic exposures, and rugged faulting patterns at the Mid-Atlantic Ridge $\left(22^{\circ}-24^{\circ} \mathrm{N}\right)$, Geology, 23, 49-52, 1995.

Cannat, M., Y. Lagabrielle, N. de Coutures, H. Bougault, J. F. Casey, L. Dmitriev, and Y. Fouquet, Ultramafic and gabbroic exposures at the Mid-Atlantic Ridge: Geological mapping in the $15^{\circ} \mathrm{N}$ region, Tectonophys., 279, 193-214, 1997.

Casey, J. F., and T. Fujiwara, Definition of an abrupt transition between regions of abundant and extremely low magma supplies along the Mid-Atlantic between $14^{\circ}$ and $16^{\circ} \mathrm{N}(\mathrm{ab}-$ stract), EOS Trans. $A G U, 82,1,102,2001$.

Casey, J. F., W. B. Bryan, C. Xia, S. E. Smith, S. Silantiev, and L. Dmitriev, Basaltic compositional trends, 12 to $38^{\circ} \mathrm{N}$ along the Mid-Atlantic Ridge: Local paradigms, Eos Trans. $A G U$, 73, 584, 1992.

Casey, J. F., W. F. Bryan, and S. Silantyev, Comparison of the geochemistry of basaltic, plutonic and residual mantle rocks from the Mid-Atlantic Ridge: Evidence of near fractional melting and mixing, Eos Trans. AGU, 75, 657, 1994.

Casey, J. F., M. G. Braun, T. Fujiwara, T. Matsumoto, and P. B. Kelemen, Megamullions along the Mid-Atlantic Ridge between $14^{\circ}$ and $16^{\circ} \mathrm{N}$ : Results of Leg 1, JAMSTEC/WHOI MODE 98 survey, Eos Trans. AGU, 79, 920, 1998.

DeMets, C., R. G. Gordon, D. F. Argus, and S. Stein, Current plate motions, Geophys, J. Int., 101, 425-478, 1990.

Detrick, R. S., and J. A. Collins, Seismic structure of ultramafics exposed at shallow crustal levels in the Mid-Atlantic Ridge rift valley at $15^{\circ} \mathrm{N}$ (abstract), Eos Trans. AGU, 79, 800, 1998.

Detrick, R. S., H. D. Needham, and V. Renard, Gravity anomalies and crustal thickness variations along the Mid-Atlantic Ridge between $33^{\circ} \mathrm{N}$ and $40^{\circ} \mathrm{N}$, J. Geophys. Res., 100, 3767-3787, 1995.

Dick, H. J. B., and P. B. Kelemen, Light rare earth element enriched clinopyroxene in harzburgite from $15^{\circ} 05^{\prime} \mathrm{N}$ on the Mid-Atlantic Ridge, Eos Trans. $A G U, 73,584,1992$.

Dick, H. J. B., R. L. Fisher, and W. B. Bryan, Mineralogic variability of the uppermost mantle along mid-ocean ridges, Earth Planet. Sci. Lett., 69, 88-106, 1984.

Dosso, L., B. B. Hanan, H. Bougault, J.-G. Schilling, and J.-L. Joron, Sr-Nd-Pb geochemical morphology between $10^{\circ}$ and $17^{\circ} \mathrm{N}$ on the Mid-Atlantic Ridge: A new MORB isotope signature, Earth Planet. Sci. Lett., 106, 29-43, 1991.

Dosso, L., H. Bougault, and J.-L. Joron, Geochemical morphology of the North Mid-Atlantic Ridge, $10^{\circ}-24^{\circ} \mathrm{N}$ : Trace element-isotope complementarity, Earth Planet. Sci. Lett., 120, 443-462, 1993.

Escartín, J., and M. Cannat, Ultramafic exposures and the gravity signiture of the lithosphere near the Fifteen-Twenty Fracture Zone (Mid-Atlantic Ridge, $14^{\circ}-16.5^{\circ} \mathrm{N}$ ), Earth Planet. Sci. Lett., 171, 411-424, 1999.

Escartín, J., and C. J. MacLeod, Mechanisms and conditions of deformation along an oceanic detachment (Mid-Atlantic Ridge, Fifteen-Twenty Fracture Zone), Eos Trans. AGU, 82, 1101, 2001.

Fujiwara, T., and H. Fujimoto, Seafloor geomagnetic vector anomaly of the intersection of the Mid-Atlantic Ridge and the Kane Transform Fault: Implications for magnetization of the oceanic crust, J. Geophys. Res., 103, 30,335-30,349, 1998.

Fujiwara, T., T. Matsumoto, P. B. Kelemen, M. Joshima, J. F. Casey, A. Takeuchi, G. M. Ceuleneer, M. G. Braun, and S. Kanda, Bathymetry, geomagnetic and gravity anomalies of the Mid-Atlantic Ridge between $14^{\circ} \mathrm{N}$ and $16^{\circ} \mathrm{N}, J A M$ STEC, J. Deep Sea Res. Part II, 15, 13-27, 1999.

Grindlay, N. R., P. J. Fox, and P. R. Vogt, Morphology and tectonics of the Mid-Atlantic Ridge $\left(25^{\circ}-27^{\circ} 30^{\prime} \mathrm{S}\right)$ from Seabeam and magnetic data, J. Geophys. Res., 97, 69837010, 1992.

International Association of Geodesy (IAG), Geodetic Reference System 1967, Bureau Central de A.I.G. Spec. Pub. 3, Copenhagen, Denmark, 1967.

International Association of Geomagnetism and Aeronomy (IAGA) Division V Working Group 8, International Geomagnetic Reference Field, 1995 revision, J. Geomag. Geoelectr., 47, 1257-1261, 1995.

Karson, J. A., and R. M. Lawrence, Tectonic window into gabbroic rocks of the middle oceanic crust in the MARK area near Sites 921-924, Proc. Ocean Drill Program Sci. Results, 153, 61-76, 1997.

Karson, J. A., et al., Along-axis variations in seafloor spreading in the MARK area, Nature, 328, 681-685, 1987.

Kelemen, P. B., and T. Matsumoto, Geological results of MODE 98, Leg 1: JAMSTEC/WHOI Shinkai 6500 submersible and shipboard geophysics cruise to $15^{\circ} \mathrm{N}$, Mid-Atlantic Ridge, Eos Trans. AGU, 79, 45, 1998.

Kuo, B. Y., and D. W. Forsyth, Gravity anomalies of the ridgetransform system in the South Atlantic between $31^{\circ}$ and $34.5^{\circ} \mathrm{S}$ : Upwelling centers and variations in crustal thickness, Mar. Geophys. Res., 10, 205-232, 1988.

Lagabrielle, Y., D. Bideau, M. Cannat, J. A. Karson, and C. Mével, Ultramafic-mafic plutonic rock suites exposed along the Mid-Atlantic Ridge $\left(10^{\circ} \mathrm{N}-30^{\circ} \mathrm{N}\right)$, Symmetricalasymmetrical distribution and implications for seafloor spreading processes, in Faulting and Magmatism at MidOcean Ridges, Geophys. Monogr. Ser, vol. 106, edited by W. R. Buck et al., pp. 153-176, AGU, Washington, D.C., 1998.

Lin, J., G. M. Purdy, H. Schouten, J.-C. Sempéré, and C. Zervas, Evidence from gravity data for focused magmatic accretion along the Mid-Atlantic Ridge, Nature, 344, 627-632, 1990.

Macdonald, K. C., S. P. Miller, S. P. Huestis, and F. N. Spiess, Three-dimensional modeling of a magnetic reversal boundary from inversion of deep-tow measurements, J. Geophys. Res., 85, 3670-3680, 1980.

MacLeod, C. J., and J. Escartín, Geological constraints on ocean-floor detachment faulting (Mid-Atlantic Ridge, Fifteen-Twenty Fracture Zone), Eos Trans. AGU, 82(47), Fall Meet. Suppl., F1101, 2001.

Matsumoto, T., and P. B. Kelemen, Preliminary result of the precise geological mapping of the Mid-Atlantic Ridge $14^{\circ}-$ $16^{\circ} \mathrm{N}$ - tectonic extension along the magma-poor ridge axis, Eos Trans. AGU, 79, 46, 1998.

Morris, E., and R. S. Detrick, Three-dimensional analysis of gravity anomalies in the MARK area, Mid-Atlantic Ridge $23^{\circ} \mathrm{N}$, J. Geophys. Res., 96, 4355-4366, 1991. 
Müller, R. D., and W. H. F. Smith, Deformation of the oceanic crust between the North American and South American plates, J. Geophys. Res., 98, 8275-8291, 1993.

National Geophysical Data Center (NGDC), ETOPO5 bathymetry/topography data, data announce, 88-MGG-02, Natl. Oceanic and Atmos. Admin., U.S. Dept. of Comer., Boulder, Colo., 1988.

Oshida, A., and T. Furuta, New geophysical data logging system of R/V "Yokosuka”, J. Deep Sea Res., 11, 421-435, 1995.

Pariso, J. E., J.-C. Sempéré, and C. Rommevaux, Temporal and spatial variations in crustal accretion along the MidAtlantic Ridge $\left(29^{\circ}-31^{\circ} 30^{\prime} \mathrm{N}\right)$ over the last 10 m.y.: Implications from a three-dimensional gravity study, J. Geophys. Res., 100, 17,781-17,794, 1995.

Pariso, J. E., C. Rommevaux, and J.-C. Sempéré, Three-dimensional inversion of marine magnetic anomalies: Implications for crustal accretion along the Mid-Atlantic Ridge $\left(28^{\circ}-31^{\circ} 30^{\prime} \mathrm{N}\right)$, Mar. Geophys. Res., 18, 85-101, 1996.

Parker, R. L., and S. P. Huestis, The inversion of magnetic anomalies in the presence of topography, J. Geophys. Res., 79, 1587-1593, 1974.

Parsons, B., and J. G. Sclater, An analysis of the variation of ocean floor bathymetry and heat flow with age, J. Geophys. Res., 82, 803-827, 1977.

Peyve, A. A., Y. N. Raznitsin, S. M. Lyapunov, and S. G. Scolotnev, Mantle heterogeneity in the area of Cape Verde Fracture Zone in the central Atlantic according to the data on basalts (in Russian), Dokl. Acad. Sci. USSR Earth Sci. Sect., 301, 165-168, 1988a.

Peyve, A. A., N. M. Suchevskaya, S. M. Lyapunov, and N. N. Konokova, Peculiarities of tholeiitic magmatism in the area of the Cape Verde Fracture Zone in the Atlantic $(13-15 \mathrm{~N})$ (in Russian), Dokl. Acad. Sci. USSR Earth Sci. Sect., 302, 1174-1178, 1988b.

Phipps Morgan, J., and D. W. Forsyth, Three-dimensional flow and temperature perturbations due to a transform offset: Effects on oceanic crustal and upper mantle structure, J. Geophys. Res., 93, 2955-2966, 1988.

Prince, R. A., and D. W. Forsyth, Horizontal extent of anomalously thin crust near the Vema Fracture Zone from the three-dimensional analysis of gravity anomalies, J. Geophys. Res., 93, 8051-8063, 1988.

Reid, I., and H. R. Jackson, Oceanic spreading rate and crustal thickness, Mar. Geophys. Res., 5, 165-172, 1981.

Roest, W. R., and B. J. Collette, The Fifteen-Twenty Fracture Zone and the North American-South American plate boundary, J. Geol. Soc. London, 143, 833-843, 1986.

Rona, P. A., L. Widenfalk, and K. Boström, Serpentinized ultramafics and hydrothermal activity at the Mid-Atlantic Ridge crest near $15^{\circ} \mathrm{N}$, J. Geophys. Res., 92, 1417-1427, 1987.

Sandwell, D. T., and W. H. F. Smith, Marine gravity anomaly from Geosat and ERS 1 satellite altimetry, J. Geophys. Res., 102, 10,039-10,054, 1997.

Sleep, N. H., Formation of oceanic crust: Some thermal constraints, J. Geophys. Res., 80, 4037-4042, 1975.
Sobolev, A. V., L. V. Dmitriev, O. P. Tsamerian, V. A. Simonov, S. G. Skolotnev, and B. A. Basilev, On the structure and origin of geochemical anomaly in basalts from Mid-Atlantic Ridge between 12 and $18^{\circ} \mathrm{N}$ (in Russian), Dokl. Acad. Sci. USSR Earth Sci. Sect., 326, 541546, 1992a.

Sobolev, A. V., O. P. Tsamerian, and L. V. Dmitriev, The geochemical anomaly in Mid-Atlantic Ridge basalts between $12^{\circ}-18^{\circ} \mathrm{N}$ : Geochemical structure and origin, paper presented at the 29th International Geologial Congress, Japan, $1992 b$.

Sobolev, A. V., O. P. Tsamerian, L. V. Dmitriev, and B. Basilev, The correlation between the mineralogy of basalt and the associated peridotites: The data from the MAR between 8 18N, Eos Trans. AGU, 73, 584, 1992c.

Staudacher, T., P. Sarda, S. H. Richardson, C. J. Allègre, I. Sagna, and L. V. Dmitriev, Noble gases in basalt glasses from a Mid-Atlantic Ridge topographic high at $14^{\circ} \mathrm{N}$ : Geodynamic consequences, Earth Planet. Sci. Lett., 96, 119133, 1989.

Tivey, M. A., Vertical magnetic structure of ocean crust determined from near-bottom magnetic field measurements, J. Geophys. Res., 101, 20,275-20,296, 1996.

Tucholke, B. E., and J. Lin, A geological model for the structure of ridge segments in slow spreading ocean crust, J. Geophys. Res., 99, 11,937-11,958, 1994.

Tucholke, B. E., J. Lin, and M. C. Kleinrock, Mullions, megamullions, and metamorphic complexes on the Mid-Atlantic Ridge, Eos Trans. AGU, 77, 724, 1996.

Tucholke, B. E., J. Lin, and M. C. Kleinrock, Megamullions and mullion structure defining oceanic metamorphic complexes on the Mid-Atlantic Ridge, J. Geophys. Res., 103, 9857-9866, 1998.

Weiland, C. M., K. C. Macdonald, and N. R. Grindlay, Ridge segmentation and the magnetic structure of the southern Mid-Atlantic Ridge $26^{\circ} \mathrm{S}$ and $31-35^{\circ} \mathrm{S}$ : Implications for magmatic processes at slow spreading centers, J. Geophys. Res., 101, 8055-8073, 1996.

Wernicke, B., and G. J. Axen, On the role of isostasy in the evolution of normal fault systems, Geology, 16, 848-851, 1988.

Wessel, P., and W. H. F. Smith, New version of Generic Mapping Tools released, Eos Trans. AGU, 76, 329, 1995.

Wooldridge, A. L., C. G. A. Harrison, M. A. Tivey, P. A. Rona, and $\mathrm{H}$. Schouten, Magnetic modeling near selected areas of hydrothermal activity on the Mid-Atlantic and Gorda ridges, J. Geophys. Res., 97, 10,911-10,926, 1992.

Xia, C., J. F. Casey, S. Silantiev, and L. Dmitriev, Geochemical structure of the $14^{\circ} \mathrm{N}$ mantle source anomaly along the MidAtlantic Ridge and geochemical changes across the $15^{\circ} 20^{\prime} \mathrm{N}$ Fracture Zone, Eos Trans. AGU, 72, 518, 1991.

Xia, C., J. F. Casey, S. Silantiev, L. Dmitriev, and H. Bougault, Geochemical variations between 12 to $16^{\circ} \mathrm{N}$, Mid-Atlantic Ridge: A region with high degrees of partial melting yet magma starved?, Eos Trans. AGU, 73, 553, 1992. 